\title{
A MUNKÁVAL KAPCSOLATOS ÉRTÉKEK KÖZÉP-KELET-EURÓPÁBAN - NEMZETKÖZI FELMÉRÉSEK TÜKRÉBEN
}

Az elmúlt évtizedekben számos tényezố együttes hatása következtében jelentôs változások következtek be világszerte a munka szférájában, megváltoztatva a szervezetek és a kereteik között folyó munka számos jellemzôjjét. Két évtizeddel ezelótt alig álltak rendelkezésünkre a vezetést szolgáló olyan reprezentatív nemzetközi felméréseredmények, amelyekbe a közép- és kelet-európai országok is bekapcsolódtak volna. Azóta azonban leomlottak az akadályok, és örvendetesen megnôtt az érdeklódés a kultúraközi kooperációt és kommunikációt érintő kérdések kutatása iránt. A szerzó tanulmánya az EVS közzétett felmérési adataiból kiindulva tesz összevetéseket a GLOBE/kutatás eredményeivel és a „kulturális standardok” modellre épüló megfigyelésekkel. Arra keresi a választ, hogy mennyire homogén a munkához kapcsolódó értékek terén a közép- és kelet-európai tömb, és mennyiben térnek el ezek az értékek a többi európai országra jellemzó adatoktól. A szerzó kiemelte a munka és a munkahely bizonyos aspektusainak fontosságát, a vezetô utasításához való viszonyulást. Az összehasonlítás alapját 33 európai ország, és ezek bontása, 14 kelet-európai, valamit 19 nyugat-, észak- és dél-európai ország adatai képezik.

Kulcsszavak: a munkával kapcsolatos értékrend, Közép-Kelet-Európa, EVS, GLOBE, a kulturális standardok módszere

Az elmúlt évtizedekben különböző tényezók együttes hatása következtében világszerte jelentôs változások következtek be a munka szférájában. Átalakult a szervezetek és a kereteik között folyó munka számos jellemzője, átértékelődtek például a munka különbözô aspektusai, megváltozott a munkaerónek a munkához fúződő viszonya, magasabbak lettek a kereseti elvárások, nagyobb a szervezeti döntésben való részvétel igénye és erôsebb a megbecsülést tükröző bánásmód és az igazságosság iránti vágy. Ezzel párhuzamosan számos nemzetgazdaságban magas a munkanélküliségi ráta, másutt bizonyos szakképzettségekben mutatkozó hiány zavarja az egyensúlyt. A globalizáció térhódítása pedig a vállalatokon belül is a kultúrák mind gyakoribb találkozását hozza magával, ami a vállalatvezetôket a kultúrák közötti különbségekból eredő sajátos problémák kezelésére kényszeríti, és megnehezíti egy szilárd értékrendú, homogén szervezeti kultúra kialakítását.

Elsősorban e változásoknak tulajdonítható, hogy az 1980-as évektól élénk érdeklődéssel fordulnak a kuta- tók a munkával kapcsolatos attitúdök és a kultúratényezók kérdéséhez. A menedzsment nézőpontjából különösen ismertté váltak Hofstede (1980), Trompenaars (1993) eredményei.

Minthogy 1990 előtt a közép- és kelet-európai országok gazdaságilag kevéssé voltak nyitottak Nyugat felé, a Hofstede és munkatársai által az IBM-nél végzett nagy mintavételú felmérés nem terjedhetett ki a kelet-európai országokra - Jugoszlávia kivételével. A kutatók azonban a vasfüggöny mögött is több országban követték a Nyugat-Európában és Amerikában folyó kutatásokat, és lehetôségeik keretei között igyekeztek ezekkel lépést tartani. Jellemző, hogy Magyarországon már 1983-ban végeztek felmérést Hofstede dimenzióit használva - még ha nem is az eredeti nemzetközi kutatás részeként. Az eredmények azonban nem kaptak kellôen széles körú publicitást (Varga, 1983). Annak megállapítására, hogy a kelet-európai nemzetek hol foglalnak helyet a Hofstede-féle rangsorban, csupán becslések folytak (ITIM, 1996) ${ }^{1}$. 
Az 1990-es években azonban nagy lendületet vettek a menedzsment-nézópontú kultúra-összehasonlító munkák Magyarországon és más kelet-európai országban is. Tudósok sokasága kapcsolódott be a nemzetközi felmérésekbe vagy dolgozott önállóan, átvéve a nemzetközi kutatások módszereit. Ezek közül kiemelkedik az EVS- ${ }^{2}$, a GLOBE- ${ }^{3}$, a STRATOS ${ }^{4}$-programokba történt bekapcsolódás. A magyar kép teljesebbé válásához azonban jelentősen hozzájárultak más, kvantitatív és kvalitatív módszerekkel ${ }^{5}$, például a kulturális standardok modell alapján végzett felmérések ${ }^{6}$ is. Sajnálatos, hogy ezen eredmények sokszor kis példányszámban, kevesekhez eljutó kiadványokban jelentek meg.

Jelen dolgozat e gazdag eredményekból csak a munkával kapcsolatos értékeket emeli ki, és kísérletet tesz a különbözó módszerekkel nyert adatok és megállapítások közötti összefüggések keresésére.

\section{A munkával kapcsolatos értékek az EVS-kutatásban}

A European Values Study (EVS) elnevezésú, nemzetközi longitudinális vizsgálatot a Tilburgi Egyetem és a Leuveni Katolikus Egyetem kutatói indították az 1970-es évek végén a nyugati társadalmak alapvetô értékeinek kutatására. Kiinduló kérdésük az volt, hogy létezik-e még (létezett-e még a 70-es évek végén) az az egységesség az európai kultúrában, amely a kereszténység hatására hajdan kialakult. A cél pedig, hogy empirikus módszerrel tárják fel az európaiak értékrendi jellemzóit. A felmérést első hullámban 1981-ben végezték el az akkori Európai Közösség országaiban és Spanyolországban. A kutatás hamarosan Európán kívüli szakemberek érdeklődését is felkeltette, és a Michigan Egyetem profeszszorának, Ronald Inglehardnak a bekapcsolódásával tengerentúli intézmények is csatlakoztak a kutatáshoz. Valamennyien az EVS kérdőívét és feldolgozási módszereit használták. Így az EVS-ból kinőtt a világot átfogó World Value Survey (WVS).

A változásokat is mérendő 1990-ben új adatgyújtés történt. E körben Görögország kivitelével az Európai Közösség valamenynyi országa, néhány kelet-európai ország, és Norvégiát leszámítva a skandináv országok is részt vettek.

Az 1999/2000-ben lefolytatott újabb, harmadik felméréshullám megismételte a korábbiak kérdésköreit. Ezek: a legfontosabb életterületek (így pl. a család, a munka, a vallás stb.) fontossága; a társadalmi kérdések megítélése, a politika, a környezettudatosság jelenléte a társadalomban, továbbá számos morális kérdés éppúgy, mint a társadalom különböző csoportjai (bevándorlók, etnikai kisebbségek) iránti attitúdök.

Az EVS harmadik hulláma 32 európai országra terjed ki, és 39.797 európai válaszadó véleményét dolgozza fel, de a WVS eredményeivel együtt már az egész világot átfogja. Országonként 1000 és 2000 között van a megkérdezettek száma. Az egységes kérdőív alapján végzett reprezentatív felmérést szakemberek (többnyire a Gallup Intézet) végzik. Az eddig legátfogóbb értékrendi kutatás azért is különös jelentőségú, mert az egy idóben nyert adatok jó kiindulást nyújtanak az európai országok - beleértve a kelet-közép-európaiakat is - nemzeti kulturális jellemzóinek összevetésére. Írásom e felmérés adatbázisából merít (Halman, 2003).

A hatalmas adatbázisból jelen tanulmányomban csupán egy szúk szegmenst emelek ki, és az összehasonlítást $33^{7}$ európai ország (EU-33) ${ }^{8}$, ezek közül 14 közép- és kelet-európai ország (EU-14) ${ }^{9}$ és a további 19 (EU-19) ${ }^{10}$ átlagértékeire korlátozom.

\section{Az élet néhány fontos komponense az európaiak értékrendjében}

$\mathrm{Az}$ élet fontos komponensei nagy hatással vannak a munkavállalásra és munkavégzésre is. A munkában érzett motiváltság, a munkahelyhez kötődés mértéke szorosan összefügg azzal is, hogy más életterületek, így a család, a barátok és ismerôsök, a szabadidő, a vallás és a politika milyen szerepet játszanak és mennyire fontosak az egyén életében.

\section{A család, a barátok, a szabadidó, a vallás} és a politika fontossága

A válaszadók e kérdéskörben arról alkotva véleményt, hogy mennyire fontos számukra az élet egy-egy komponense, a nagyon, az eléggé, a nem és az egyáltalán nem fontos válaszok közt választhattak. A család kiemelkedően fontos az európai értékrendben. Az összes (a norvégokkal együtt több mint 40.000) válasz közül $84,5 \%$ nagyon fontos volt és csak $0,5 \%$ véli úgy, hogy számára a család egyáltalán nem fontos. Az országokat összehasonlítva kicsik az eltérések az egyes válaszlehetôségeken belül is. Máltában a válaszok 95,6\%-a volt nagyon fontos, és a családot az európai országok közül legkevésbé kiemelkedő jelentôségûnek tartó Litvániában is $65,6 \%$-ot értek el a nagyon válaszok.

1. ábra

A legfontosabb életkomponensek fontossága Európában (33 ország átlaga)

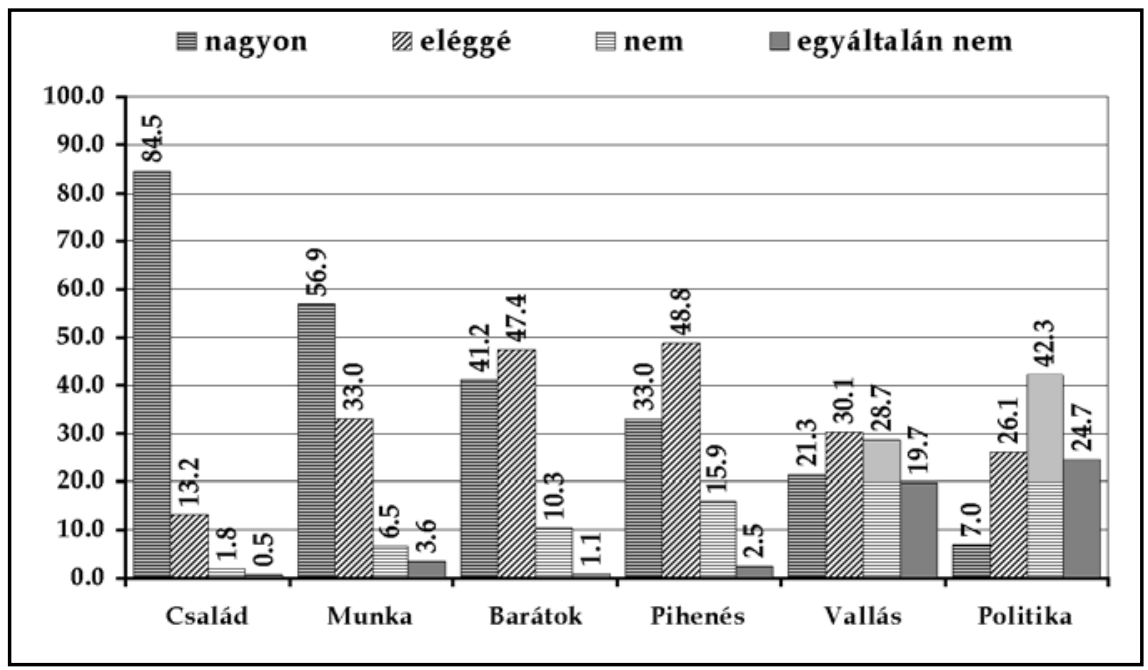


A barátok és ismerósök nagyon fontos voltának európai átlagértéke 41,2. A szélsőértékek közötti különbség itt igen nagy. Míg a svédek 70,7\%-ának nagyon fontosak a barátok, addig a litvánok közül csak 17\%-nak.

Hasonlóan nagyok az eltérések a szabadidó fontosságának tekintetében is. Az élen e tényezô vonatkozásában is a svédek, a hollandok és a britek járnak $(50 \%$ fölötti értékeikkel), míg a litvánok, a lettek és az oroszok csak $20 \%$ alatti arányban tartják nagyon fontosnak a szabadidôt. Ötödik helyre került a vallás a fontosság sorrendjében. Egy 21,3\%-os nagyon fontos európai átlag mellett nagyon távol esnek egymástól a vallást a legnagyobb arányban nagyon fontosnak találó máltaiak $(67,2 \%)$ és a legkisebb arányban nagyon fontosnak tartó csehek (7,3\%). Ugyanígy nagy az eltérés a vallást egyáltalán nem fontosnak tekintók között is, míg Máltán 1,9\%, addig Csehországban $46,4 \%$. A fontossági sorrendben a politika zárja a sort $7 \%$ nagyon fontos európai átlaggal. Az élen Málta áll 13,4\%-kal és Romániában mondják legtöbben, hogy számukra a politika egyáltalán nem fontos $(41,3 \%)$ (1. ábra).

\section{A munka fontossága}

A hat leglényegesebb életkomponens közül Európában a család mögött a második helyen a munka áll. Átlagban az európaiak 56,9\%-a számára nagyon fontos, és csak 3,5\%-a számára egyáltalán nem az. Azonban a nagyon fontos-t választók közt nemzetenként már jelentősebb az eltérés: a lengyelek járnak az élen: 78,0\%uknak nagyon fontos, és csupán 1,8\%-uknak egyáltalán nem fontos a munka, és a dánok látszanak legkevésbé tömegesen munkamániásnak: 39,5\% tartja nagyon fontosnak a munkát, többségükben az elég fontos kategóriába sorolják.

Ha mélyebbre megyünk a munka fontosságának összehasonlításában, Közép- és Kelet-Európában és Máltán jelentősen több nagyon fontos értéket találunk, mint Észak- és Nyugat-Európában. Lengyelország (78\%), Románia (70,6\%), Lettország (69,7\%) magasan felülmúlják az 56,9\%-os európai átlagot. Az európai átlag fölött foglal helyet Ukrajna, Szlovénia, Bulgária, Szlovákia és Oroszország is, vagyis a 14 közül összesen nyolc közép- és kelet-európai ország. Hozzá kell tenni, a $69,1 \%$-os francia, a 64\%-os belga érték is magas, fóként, ha mellé vesszük az „elég fontos” kategóriát is.
A franciák közül csupán 5,2\%-nak nem, vagy egyáltalán nem fontos a munka. A máltaiak között pedig csak 4,5\%-ot tesz ki e csoport. Meglepó lehet viszont, hogy a válaszadó északírek $25,5 \%$-a nem, vagy egyáltalán nem tartja fontosnak a munkát (2. ábra).

2. ábra

A munka fontossága az európai országokban

nagyon $\square$ egyáltalán nem

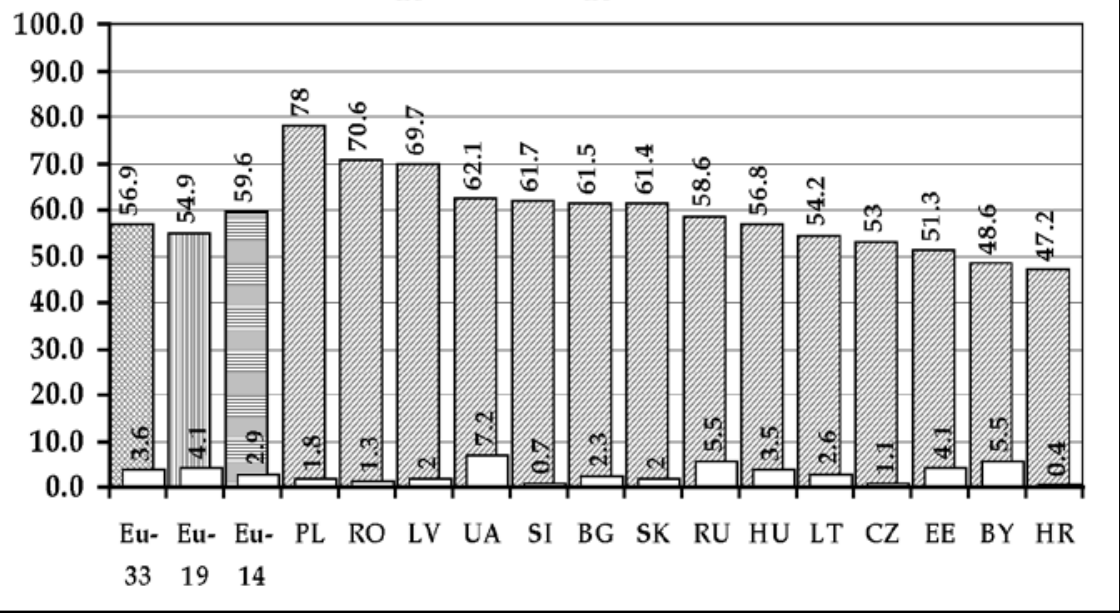

A munkához kapcsolódó értékpreferenciák

Az EVS 15 szempontot sorakoztat fel, amelyek fontosságáról az interjúalanyoknak véleményt kell mondaniuk. Ezek: a 1. jó fizetés, 2. kellemes munkatársak, 3. nem túl nagy stressz, 4. a munkahely biztos volta, 5 . az elórelépés lehetôsége, 6. a munka társadalmi respektálása, 7. jó munkaidó-beosztás, 8. kezdeményezési lehetóség, 9. a társadalom számára hasznos munka végzése, 10. sok szabadság, 11. az emberekkel való találkozás lehetốsége, 12. valami elérésének a lehetôsége, 13. felelósségteljes munka végzésének lehetósége, 14. érdekes munka, 15. az egyén képességeinek megfelelố munka. A 15 kritérium kérdésében a válaszadók arról mondtak véleményt, hogy fontos-e számukra a megnevezett szempont vagy sem.

A jó fizetés valamennyi európai országban fontos tényezó. Átlagban az európaiak több mint $80 \%$-a válaszolta azt, hogy számukra fontos a magas fizetés. (3. ábra) A kelet-európai országokra kiemelkedóen magas arány jellemző. Öt országban (BG, LT, PL, RO, SK) meghaladja a 90\%-ot. (3. ábra). Magyarországon a válaszadók közel 90\%-a tartja fontosnak a jó keresetet. Ezt a tényt erősítette meg a magyarországi STRATOSfelmérés is (Borgulya et al., 1996), Dobrai - Sümegi hazai tudásorientált kultúrájú vállalatoknál azonban azt találta, hogy alkalmazottaik az intellektuális értékeket az anyagi javadalmazás elé helyezték (Dobrai - Sümegi, 2005) (3. ábra). 


\section{A ,jó fizetés" fontossága}

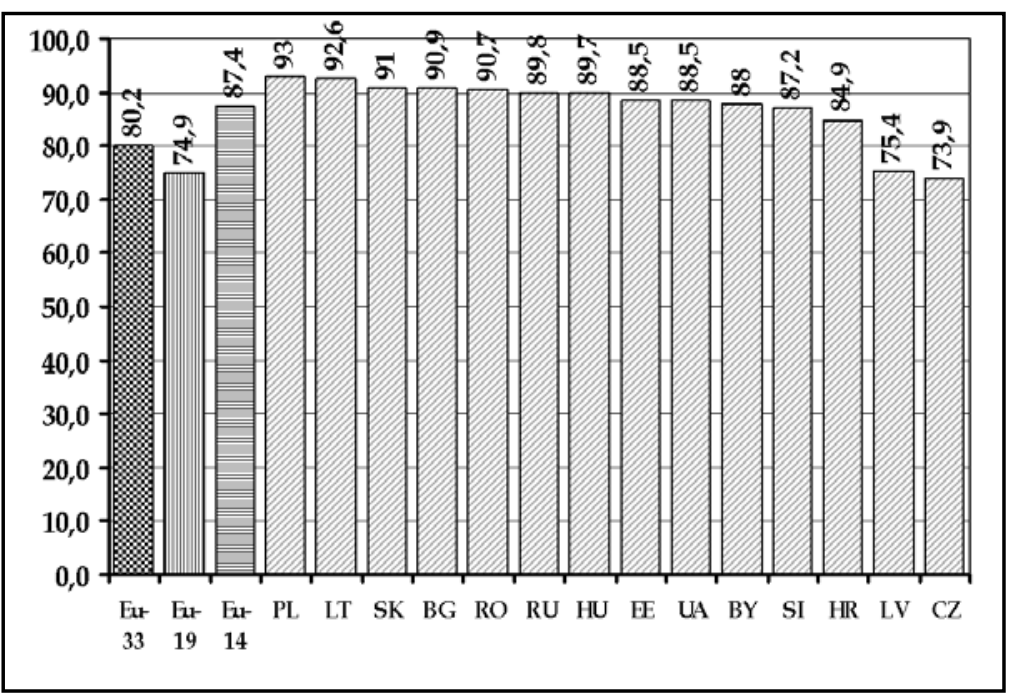

A „kellemes munkatársak” fontossága

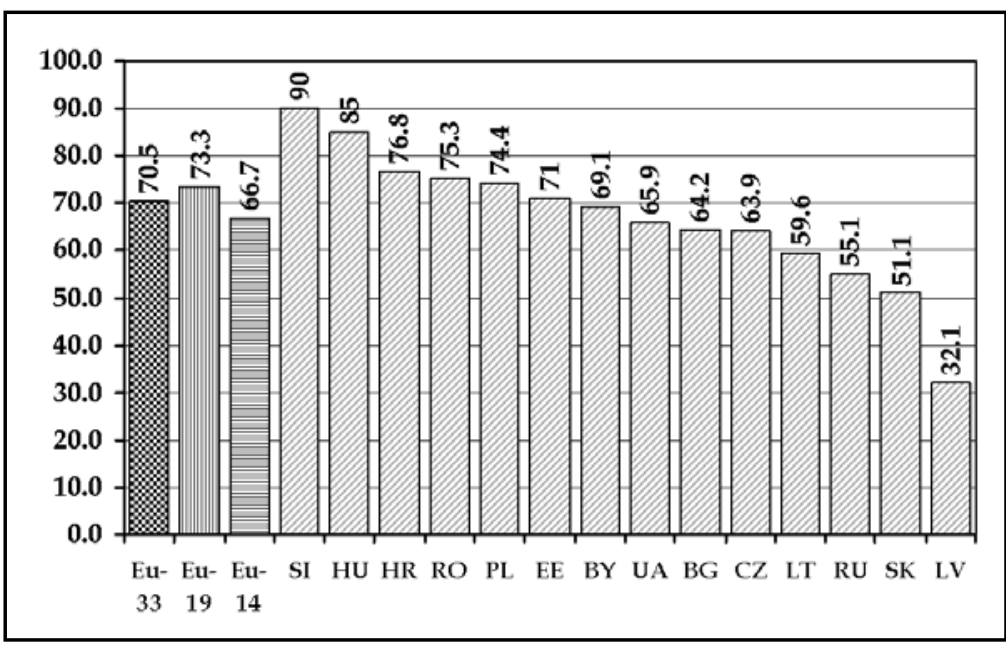

3. ábra jó fizetés, a biztos munkahely, a képességeknek megfelelő munka mögé, a negyedik helyre került, meglehetôsen magas, 85\%os mutatóval. Amennyiben nem csupán a vágy tükröződik e mutató mögött, hanem meg is valósul a kellemes munkatársi környezet, akkor nem meglepó, hogy barátságok, mély személyközi kötődések jellemzik a magyar munkahelyeket, és teret adnak szimpátián alapuló csoportok létrejöttének. Feltételezzük, az ellenkezóje is igaz. Ha az együtt dolgozók nem kellemesként élik meg a munkatársi közeget, konfliktusokkal lesz terhes a légkör, a konfliktusok pedig segítik az érdekcsoportok képződését, a „klikkesedést". Erre is bôven látunk példát a magyar gyakorlatban (4. ábra).

Az érdekes munka 66,1\%-os átlaggal a harmadik helyet foglalja el az európai fontossági rangsorban. A kelet-európai rangsorban a negyedik helyen szerepel, az egyes országok között azonban jelentôs eltérések mutatkoznak. Míg a szlovének 91,6\%-a, a horvátok $78 \%$-a, a magyarok $76,8 \%$-a vélekedik úgy, hogy számára fontos, hogy érdekes legyen a munka, addig a litvánok közül csak $48 \%$ gondolkodik hasonló módon (5. $a ́ b r a)$. Az érdekesség gyönyörködtető érzése örömtelivé teszi a dolgozást, és pszichikai „hozadékként” jelentkezik a munka során.

Európai átlagban a negyedik legfontosabb tényezố a munkahely biztonsága. E kategória a közép- és kelet-európaiak gondolkodásában azonban kiemelkedően fontos. Számukra - a
$\mathrm{Az}$ európai átlagban a fontossági sorrendben a kellemes emberekkel való együtt dolgozás szerepel a második helyen 70,5\%kal. A közép- és kelet-európai országok közül hatban haladja meg a válaszok aránya ezt a hányadot (SI, HU, HR, RO, PL, EE), ugyanakkor a keleti 14 átlaga valamivel alacsonyabb, mint a többi 19 európai országé (4. ábra). Ez az adat elgondolkoztató annak a tükrében, hogy a kelet-európai országokat a nyugat-európaiak egybehangzóan személyorientáltsággal, a munkahelyeket a magánélettel átitatott munkaszíntérként jellemzik - mint ezt a kvantitatív módszerrel végzett kutatások bemutatásánál kifejtjük. A magyarok válaszaiban ez az aspektus a
Az „érdekes munka” fontossága

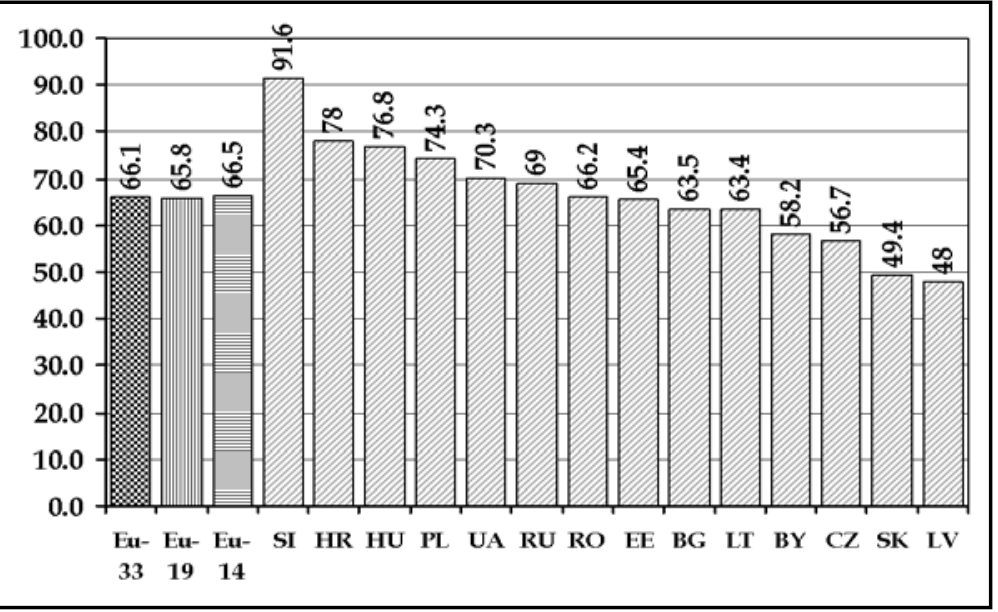


magas fizetés mögött - a második legfontosabb tényező. Tíz országban is meghaladja az európai átlagot. Legmagasabbak az értékek Magyarországon, Szlovéniában és Romániában (6. ábra). A jó fizetés és a biztos munkahely a szociális biztonság tudatának előfeltétele. Lehet-e összefüggést találni e tényezô és Hofstede bizonytalanságkerülésdimenziója között? És hogyan magyarázható, hogy bár Magyarországon a válaszadók 88,7\%-ának fontos, hogy biztos legyen a munkahelye, a munkanélküliek nehezen vállalnak munkát lakóhelyükön kívül, akár csak negyven kilométeres távolságban is. Arra pedig, hogy a biztos munka érdekében egyik településról egy másikra költözzenek, elenyészően kevesen hajlanak. E kérdésekre még visszatérünk.

\section{A „képességnek megfelelố munka” fontossága}

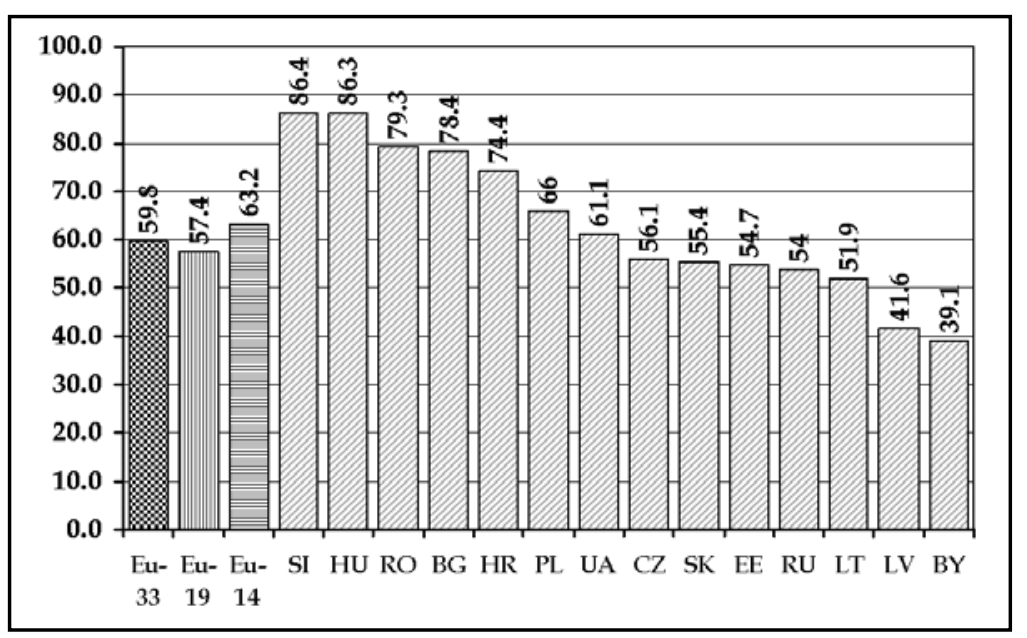

Az ,eredménnyel járó munka” fontossága

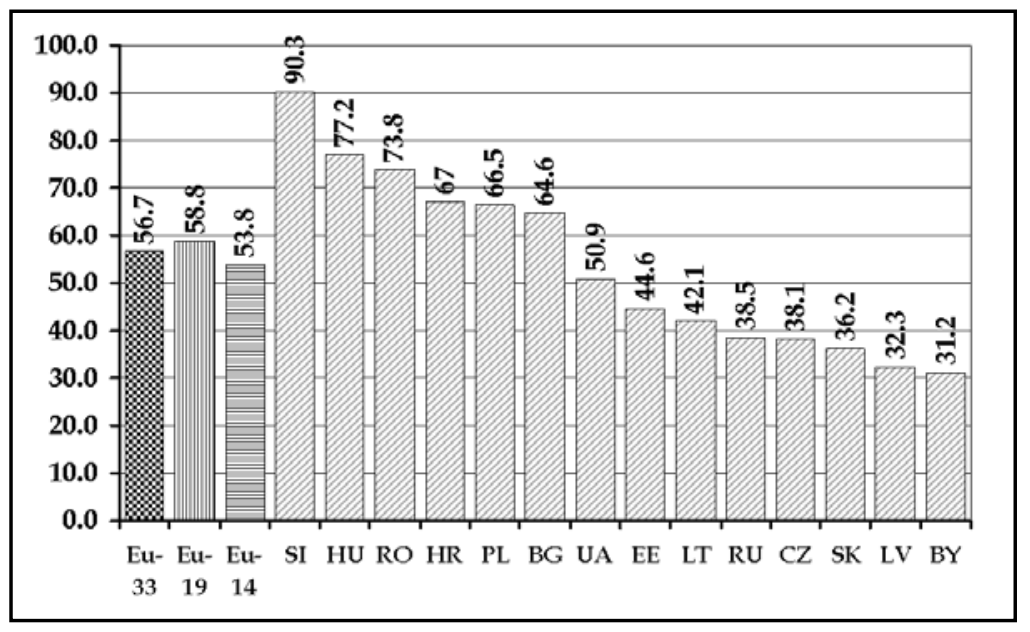

8. ábra

6. ábra

A ,munkahely biztonságának” fontossága

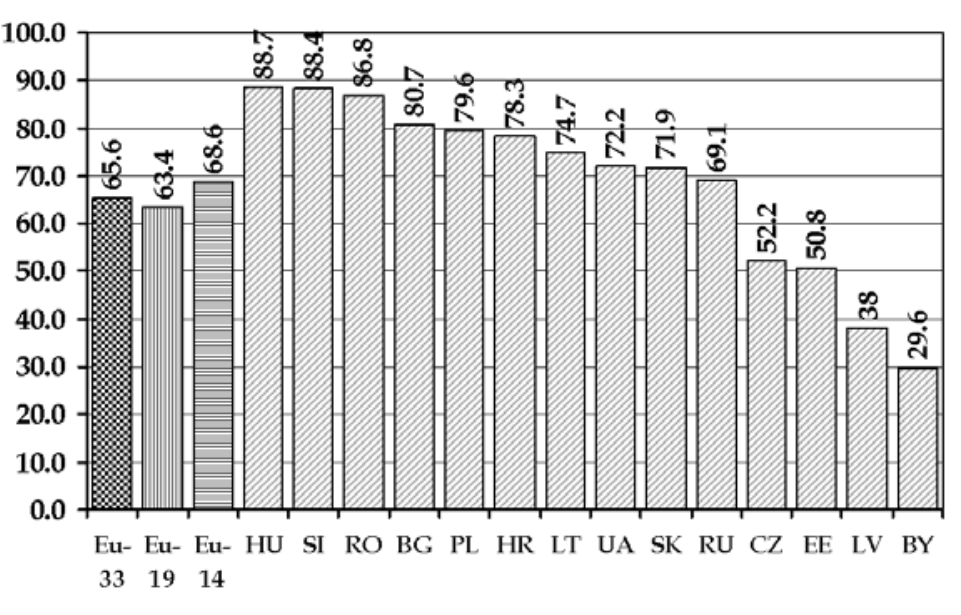

7. ábra

A munkához kötődő további aspektusok fontosságában még nagyobb eltérések találhatók a közép- és kelet-európai országok között, miközben az EU-33 átlaga az 50\% közelében mozog. Megfigyelhetjük, hogy a közép-európai országok közül Szlovénia és Magyarország kiemelkedően magasra értékeli a képességeknek megfeleló munka és az olyan munka jelentôségét, amelyben el lehet érni, fel lehet mutatni valami eredményt ( 7 . és 8. ábra). A lettek és a beloruszok azonban ezen aspektusoknak lényegesen kisebb fontosságot tulajdonítanak. Míg a szlovén és magyar arányszámok $80 \%$ körül mozognak, a lettek és beloruszok ezen átlagoknak a felét sem érik el.

A szlovének számára az eredménnyel járó munka még a magas fizetésnél és a kellemes munkatársaknál is fontosabb, meghaladja a $90 \%$-ot. A felmutatható eredmény pszichikai elégedettséget és intellektuális örömöt jelent, ezt helyezik a szlovének az anyagi ellenszolgáltatás elé. A magyarok 77,2\%-os mutatója is magas, mintegy 25 ponttal haladja meg az EU-14 átlagát.

Ismerve a magas fizetés $(89,7 \%)$, a kellemes munkatársak (85\%), a képességeknek megfelelő munka (86,3\%), valamint az eredményes munka $(77,2 \%)$ magyar mutatószámait, érdemes felfigyelni azoknak a sikeres magyarországi német vállalatoknak a vezetési rendszereire, amelyekról Gaál Zoltán, Szabó Lajos és munkatársai számolnak be. E vállalatok intuitív módon, vagy a munka- 
erő prioritásait felismerve eredmény- és feladatorientált vezetési rendszert múködtetnek, amelyek háttérfeltételei között a jó munkatársi kapcsolatokat is megtaláljuk. ,A Aállalatoknál olyan ösztönzőrendszer létezik, amely világosan definiált célok elérésén alapul. A jutalmazási rendszert a munkatársak teljesítóképességének figyelembevételével alakítják ki." ... A mindennapi munkát leginkább a kollégákhoz való jó viszony fenntartása és a munkatársak iránti segítókészség jellemzi" (Gaál et al., 2004: 32., 34. old.). A világosan és a képességeknek megfelelöen, reálisan definiált célok teljesítése kézzelfogható eredményt, örömöt jelent a vállalat dolgozói számára, ami azzal, hogy az eredmény a javadalmazásukban közvetlenül is megjelenik, további pozitív érzéseket vált ki. A szerzók megállapításai szerint az erőteljes munkatárs-orientáltság kimutatható hatással van a vezetés sikerére (Gaál - Szabó 2006: 59. old.).

Még nagyobb eltérést mutat Közép- és Kelet-Európán belül a jó idóbeosztás szempont. Míg a magyarok $79 \%$-a tartja fontosnak, hogy jó legyen a munkaidó beosztása, a letteknek csak a 18,7\%-a gondolkodik így (9. ábra). A magyarok vonatkozásában az idő jó kihasználásának fontossága teljesen érthetô, ha arra gondolunk, hogy a keresốk legtöbbje egy „főmunkahelyről” és kiegészítő jövedelemforrásokból származó bevételből biztosítja a megélhetést. A ,fómunkahely” mellett külső megbízások, magánpraxis, „fusizás”, konyhakert-múvelés stb. csak akkor végezhetók, ha sikerül a munkaidőt összehangolni.

Minthogy a közép- és kelet-európaiak számára az emberi kapcsolatok többoldalúan bizonyítottan meghatározóak, azt lehetne várni, hogy az emberekkel való találkozás lehetôsége is igen magas értékeket mutat az EVS-felmérésben. Ez az aspektus azonban nem éri el a kellemes munkatársak átlagait, bár az élen álló magyarok és szlovének esetében közel $70 \%$ az arány (10. ábra). Ebból arra lehet következtetni, hogy nem a puszta szociális érintkezés, hanem a kötődés, a kapcsolatépítés lehetőségének aspektusa a fő szempont.

A feleloósségteljes munka az európai átlagban a válaszadók közel fele számára fontos szempont (47,5\%). A magyarok, a 


\section{A „kezdeményezés lehetôségének” fontossága}

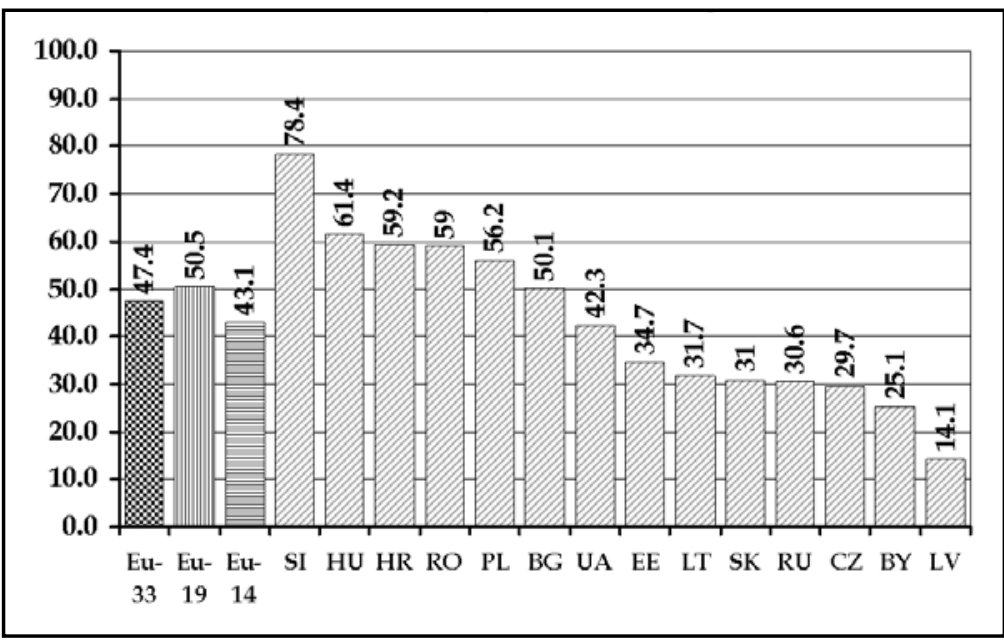

„A munka társadalmi megbecsülésének” fontossága

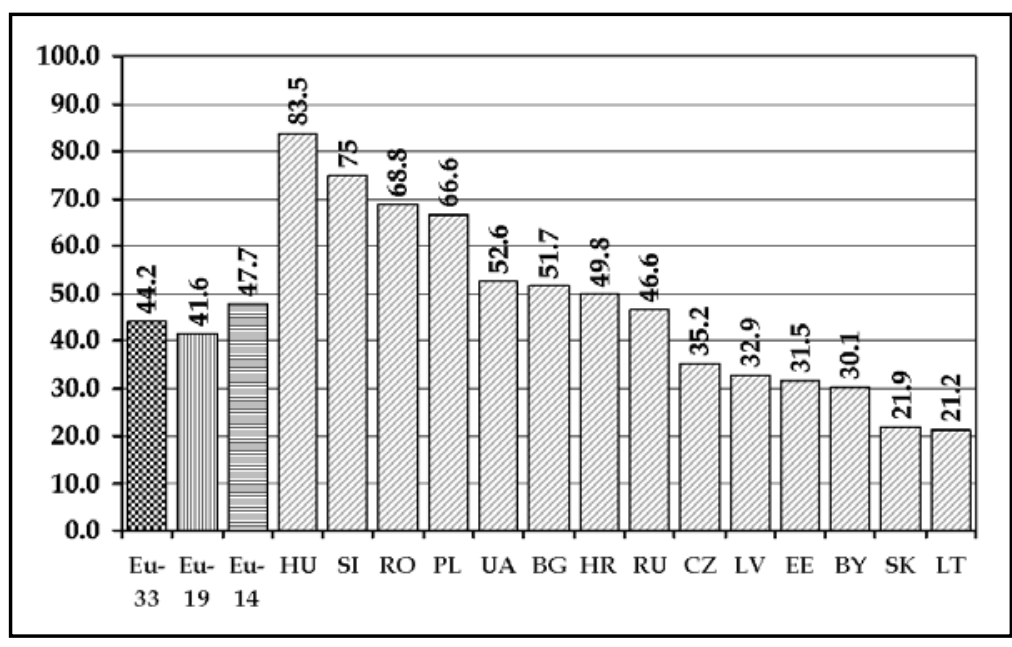

„A társadalom számára hasznos munka"

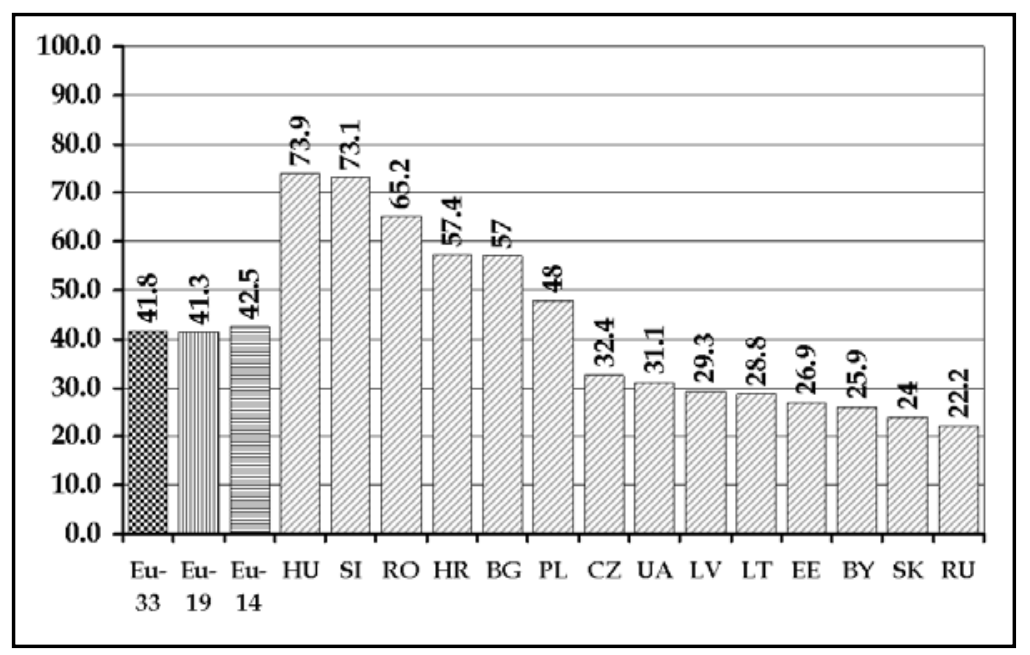

szlovének, a románok és a lengyelek e tényezőnek is jóval nagyobb jelentőséget tulajdonítanak (77,8 és 53,2 közötti átlagok), mint az európai, vagy akár a kelet-európain kívüli többi ország munkavállalói. A szovjet utódállamokban és a csehek, valamint a szlovákok körében azonban ez az arány az európai átlag felét sem éri el. A fehéroroszok közül például csupán $14,2 \%$ tartja fontosnak, hogy felelősségteljes munkát bízzanak rá (11. ábra). A 77,8\%-os magyar adat élesen ellentmond a külföldiek azon megállapításának, miszerint a magyarok (hasonlóan más posztszocialista országbeliekhez) nem szívesen vállalják a felelősséget a munkában (Szalay, 2002: 104. old.). Ugyanakkor igaznak látszik a balti országokra, Beloruszsziára és Szlovákiára is.

A jó idóbeosztáshoz hasonlóan nagy a szórás a kezdeményezés lehetôsége vonatkozásában is. Míg a szlovének 78,4\%-ban jelölték fontosnak e szempontot, addig a lettek közül csak 14,1\%-ban, és általában alacsony ez az érték a szovjet utódállamokban és a cseh, valamint a szlovák válaszadók között (12. ábra).

A kezdeményezés hiánya nem feltétlen passzivitás és érdektelenség következménye. Az innováció ösztönzésének elmaradása, a meg nem valósuló javaslatok letörik a természetes ambíciót.

A társadalom által megbecsült munka európai átlagértéke 44,2. A magyarok azonban kiugróan nagy arányban tulajdonítnak annak jelentôséget, hogy embertársaik mennyire respektálják az általuk végzett munkát. A 83,5\%-os mutatóval magasan kiemelkednek a mezónyből. Bizonyos foglalkozási csoportoknál (például a pedagógusok körében) a foglalkozás társadalmi presztízse még az alulfizetettséget is tudja valamelyest kompenzálni. Magyarországot Szlovénia követi 75\%-kal. A közép- és kelet-európai országok közül Litvániában tulajdonítanak e tényezônek legkisebb szerepet $(21,2 \%)$, de még tólük is messze elmaradnak $10,9 \%$-os mutatójukkal a dánok. E kategóriában találunk egyébként Európában legélesebb eltérést a 44,2\%-os átlag mellett (13. ábra).

A társadalom számára hasznos munka szempontja a felelősségteljes munkához hasonlóan alakul: a magyarok, a szlovének, a 
románok, a horvátok, a bolgárok sokkal fontosabbnak tartják, mint az európai átlag, hogy az általuk végzett munka a társadalom javát szolgálja. A szovjet utódállamokban, a csehek és a szlovákok számára ez a szempont nem játszik fontos szerepet (14. ábra).

Hátra sorolták az európaiak a jó elórelépési lehetốségeket. Az élen e kategóriában is a szlovének és a magyarok járnak. Közülük 73,6, illetve $67,4 \%$ tartja fontosnak a karrier lehetőségét. Magas értékeket mutat Románia, Horvátország és Málta is. A keleti csoportban rangsor végén ismét a letteket találjuk 20,1\%-kal, az európai legalacsonyabb értéket a dánoknál látjuk (17,2-es átlag) (15. ábra).

$\mathrm{Az}$ európai átlagban a rangsor végére a kevés stressz és a hosszú szabadság kategóriája került (16. és 17. ábra). A közép- és kelet-európaiak csoportján belül a stressz megítélésében a legnagyobb az eltérés: míg a szlovének 71,3\%-ának fontos, hogy a munka ne járjon sok stresszel, a letteknek csupán a 8,4\%-a tulajdonít ennek jelentőséget.

Hasonlóan élesek a különbségek a közép- és kelet-európaiak között a hosszú szabadság tekintetében is. A mezőnyből újfent a magyarok emelkednek ki 53,8\%os átlagukkal (őket az európai 33 ország rangsorában is csak az északírek előzik meg) és a lettek zárják a sort 9,9\%-kal. A fejlett európai országokban (Dániában, Svédországban, Franciaországban) csupa

\section{A ,hosszú szabadság” fontossága}

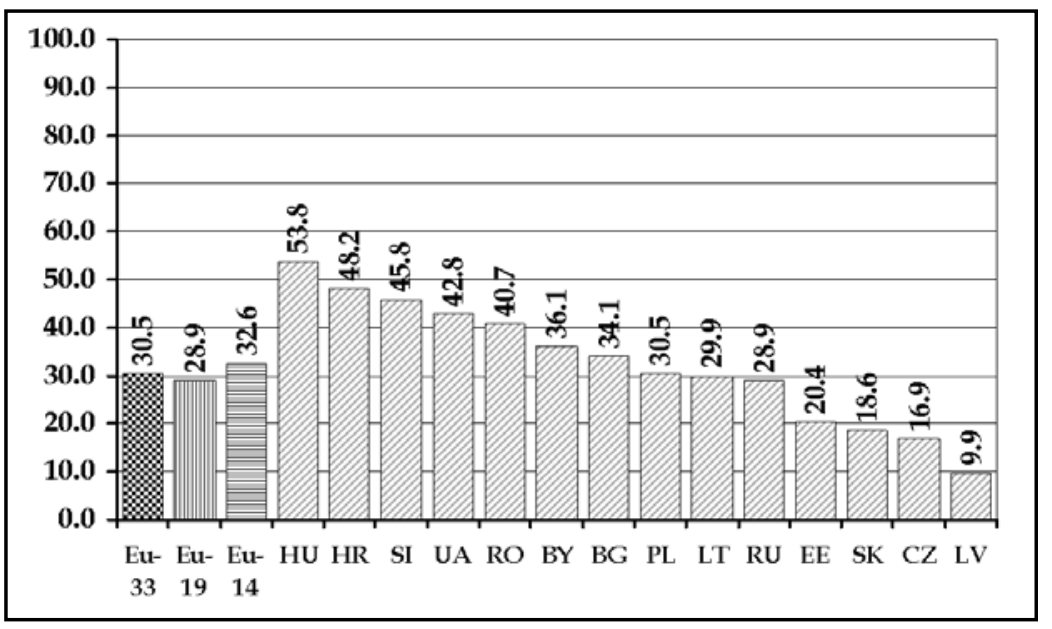

15. ábra

A ,jó elốrelépési lehetôség” fontossága

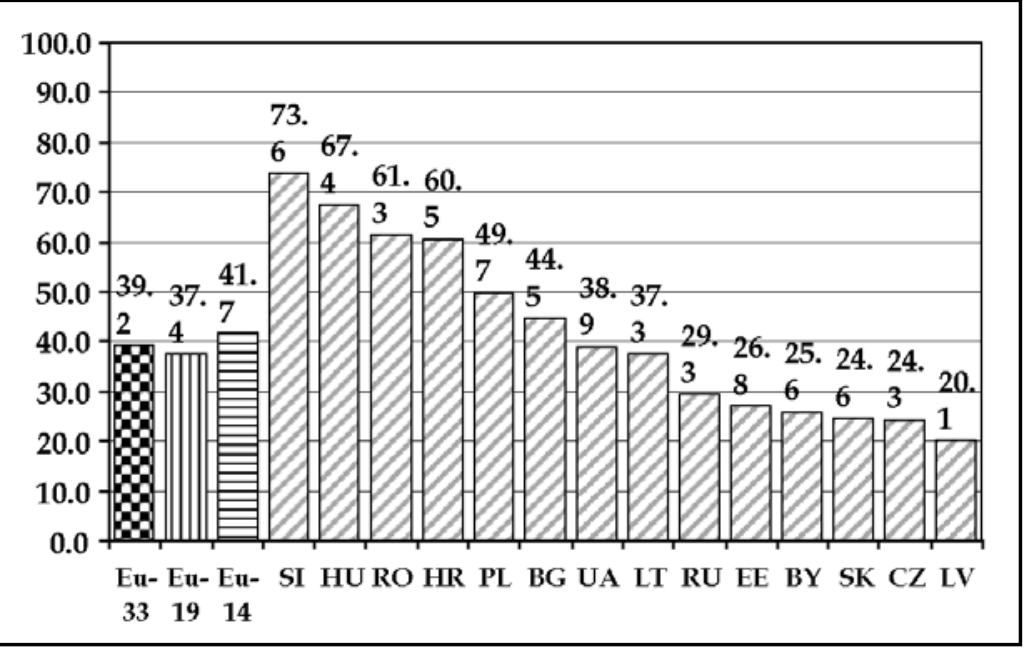

16. ábra

A ,kevés stressz” fontossága

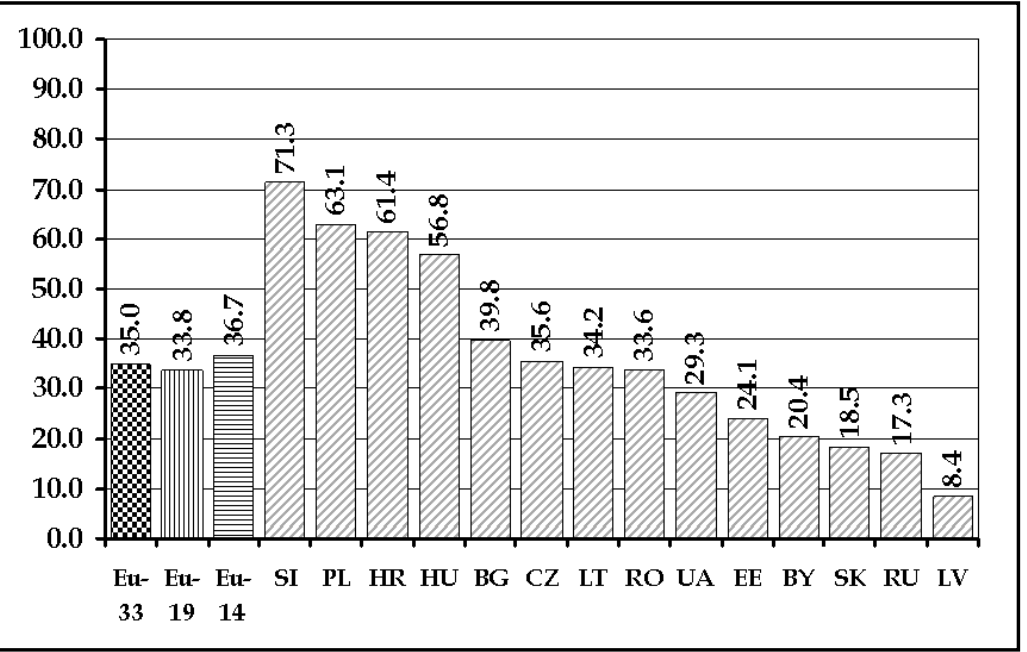

17. ábra

$20 \%$ alatti értékeket látunk, és nem tartják fontosnak a szabadságot a csehek és a szlovákok sem (17. ábra).

Összefoglalva a magyarok prioritásait, azt találjuk, hogy a tizenöt aspektus közül kilencet a válaszadók több mint háromnegyed része fontosnak tart. Sorrendben első helyes a jó fizetés $(89,7 \%)$ áll, a második helyen a biztos munkahely $(88,7 \%)$, a harmadikon a képességeknek megfeleló munka $(86,3 \%)$, negyediken a kellemes munkatársak (85\%), ötödiken a társadalom által megbecsült munka (83,5\%), hatodikon a jó idóbeosztás $(79,1 \%)$, hetediken a felelósségteljes munka (77,8\%), nyolcadikon az eredménnyel járó munka $(77,2 \%)$, kilencediken az érdekes munka (76,8\%) 
szerepel. A társadalom számára hasznosságot is közel 75\% ítélte fontosnak (73,9\%). A magyarok tehát a szociális biztonság (jó fizetés, biztos munkahely) mellett a munkában intellektuális szépséget (érdekességet), túnnek ki. A sok tényező fontossága magas motiválhatósági variabilitást sejtet, ezért ezt a csoportot sok tényezóvel motiválható csoportnak nevezem (18. ábra).

A másik csoportot SK, CZ, LV és LT alkotják, ki-

18. ábra

A sok tényezóvel motiválható közép- és kelet-európai csoport

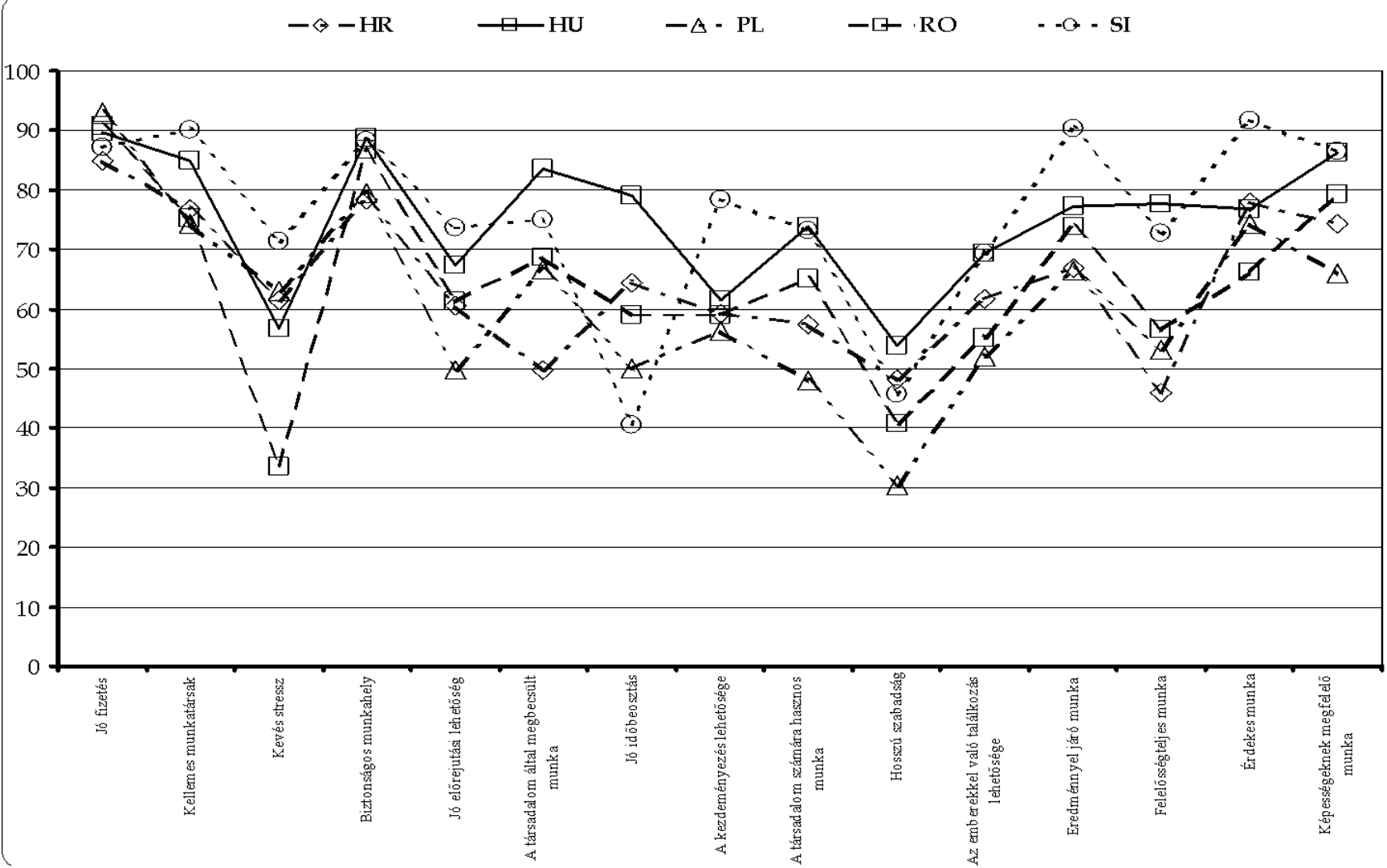

pszichikai jutalmat, örömöt (az eredményesség tudatát, a képességek kiélését, a felelősség jó érzését), szociálpszichológiai kiteljesedést (kellemes munkatársakat, társadalmi megbecsülést, mások hasznára válást) tekintik a munka fontos elemeinek. Nagy szükségük van a jó időbeosztásra, ugyanakkor valamelyest háttérbe állítják a kevés stressz és a hosszú szabadság kényelmet adó szempontjait.

A szlovénok és a magyarok igen sok szempontot tartanak fontosabbnak az európai átlagnál. Több tényezóben is listavezetók. Ez azt is jelenti, hogy sok szempont motiválja ôket a munka és munkahely megválasztásában, és közérzetük is számos tényezőtól függ.

Valamennyi a munkához kötődoó szempontot összevetve, a közép- és kelet-európai országokon belül világosan kirajzolódik két csoport, amelynek tagjai több aspektust is egymáshoz nagyon hasonlóan értékelnek. Ezek az országok egyrészt SI, HU, HR, PL, RO, amelyek az európai átlagot magasan meghaladó értékeikkel egészülve néha EE-vel és BY-vel. Ezek az országok azáltal különülnek el a többitől, hogy többnyire mélyen alatta maradnak az európai fontossági átlagoknak. Bár fontos számukra a magas fizetés, a munkahely biztonsága és hogy érdekes legyen a feladat, kevéssé fontos a jó előrejutási lehetôség, a munka általános társadalmi megbecsültsége, a kezdeményezés lehetősége, a munka társadalmi hasznossága, a munka eredményességének tudata, a feladat felelősségteljessége. Ezért ez a csoport a korlátozott eszközökkel motiválható csoport elnevezést kapja (19. ábra).

\section{A munkahelyi vezetố utasításának követése}

A munka szférájába tartozik az EVS-nek a munkahelyi vezetô és beosztottja viszonyára vonatkozó következő kérdése is: Az embereknek eltéró a véleményük a munkában kapott utasitások betartásáról. Vannak, akik azt mondják, az utasítást akkor is követni kell, ha az ember nem ért teljesen egyet azzal. Mások úgy vélik, 
Korlátozottan motiválható közép- és kelet-európai csoport

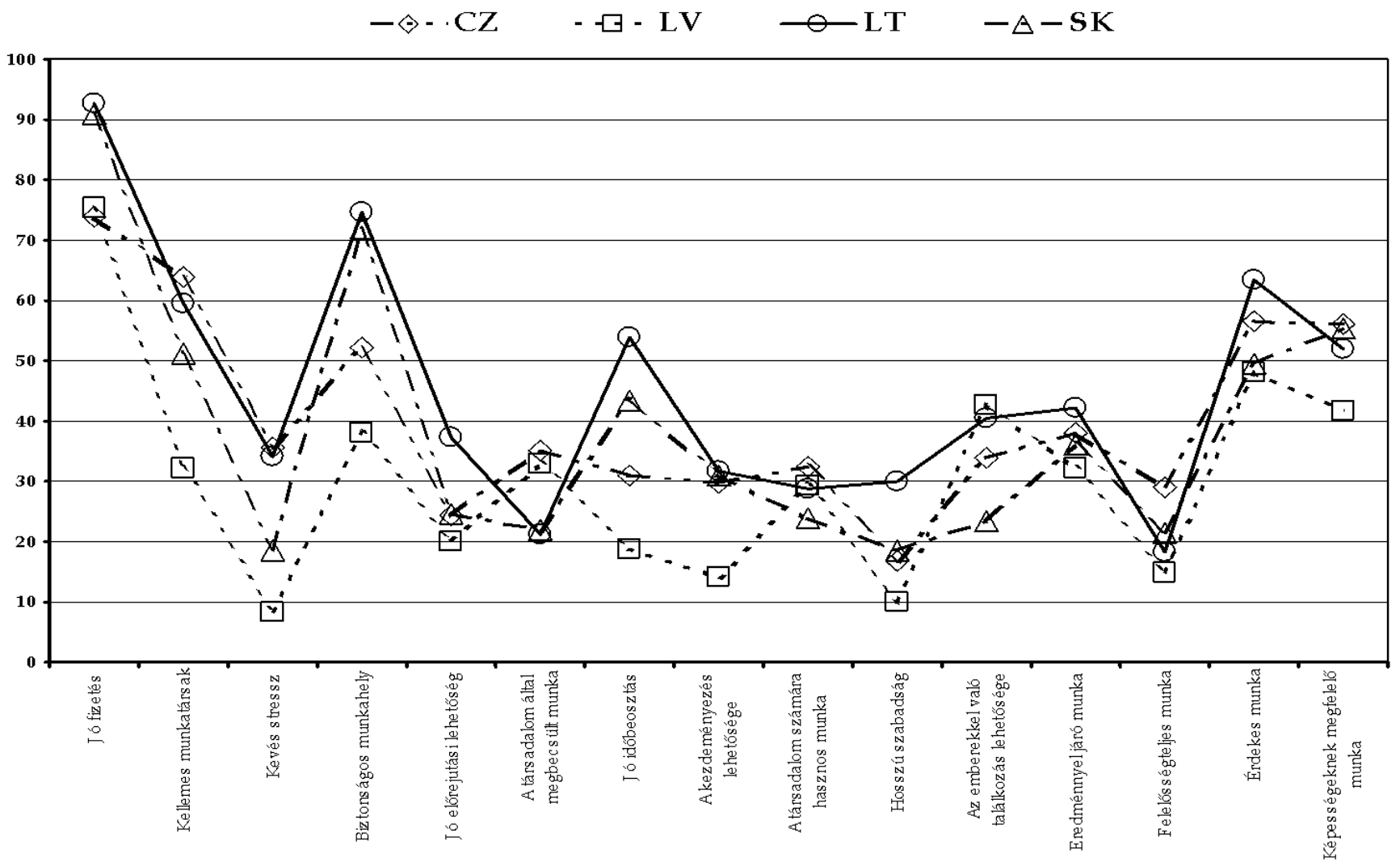

csak akkor kövesse az ember vezetójének utasitásait, ha meg van gyózódve arról, hogy azok helyesek. Mely véleménnyel ért Ön egyet?

A megkérdezettek három lehetőségból választhattak: ,mindig követni kell”, „,csak akkor, ha meg van győződve a helyességról” és ,,attól függ”. A válaszokból az túnik ki, hogy európai átlagban közel annyian követnék ellenszegülés nélkül foónökük utasítását, mint ahányan azok vannak, akik csak akkor, ha meg vannak győződve az utasítás helyességéról. A közép- és kelet-európai csoportban a magyarok közül követik legtöbben az instrukciót akkor is, ha nem értenek azzal egyet. Arányuk azonban nem éri el az 50\%-ot (43\%). Az európai átlag fölött vannak RU, UA, BG, RO és SK is. Ezzel szemben a beloruszok közül csak 16,3\%, a szlovének közül 18,7\%, a lettek közül 19,3\% hajlandók erre (20. ábra).

A horvátoknak viszont több mint fele $(55,4 \%)$ csak akkor hajlandó végrehajtani az utasítást, ha meg van győződve annak helyességéról. Más szóval, ha kételye van az utasítást illetốen, ha nem ért egyet vele, felülbírálja azt. Az európai átlagnál többen vélik a lengyelek és szlovének közül is, hogy felül kell bírálni az utasítást, ha nem értünk vele egyet (21. ábra).

\section{A GLOBE-kutatás munkával kapcsolatos következtetései}

A GLOBE-kutatás eredményei Magyarországon jól ismertek. Bakacsi Gyula és munkatársai számos publikációban adták közre vizsgálataik megállapításait: Bakacsi - Takács, 1998; Bakacsi - Takács - Karácsony - Imrek, 2002; Bakacsi, 2006. A nemzetközi irodalom is gazdag forrásul szolgál: House, 1998; House - Javidan - Hanges - Dorfman, 2002.

A GLOBE-kutatás adatai alapján a magyar kutatók (Bakacsi - Takács - Karácsony - Imrek, 2002) lehatárolták a kelet-európai klasztert, amely Albániát, Örményországot, Görögországot, Magyarországot, Kazahsztánt, Lengyelországot, Oroszországot és Szlovéniát foglalja magában.

Ezt a klasztert a magas csoportkollektivitás, magas hatalmi távolság, alacsony bizonytalanságkerülés és alacsony jövőorientáltság, a nemek viszonylagos egyenlôsége és asszertivitás jellemzi az észlelt mutatók alapján. A többi kulturális dimenzióban, mint a humánorientáció, intézményi kollektivizmus, teljesítményorientáltság a klaszter országai a középmezőnyben foglalnak helyet. (i.m.: 69., 75. old.)

Az elvárt értékekben nagyobb teljesítmény, jövő- és humánorientáltság jelenik meg. A vágyak között megtalálható a kisebb hatalmi távolság, a nagyobb strukturáltság, a feminin értékek nagyobb súlya, a nemek közötti egyenlőség magasabb szintje.

A csoportban Oroszország jellemezhetô a legnagyobb bizonytalanságtúréssel, a legalacsonyabb jövő-orientáltsági mutatóval, a legnagyobb hatalmi távolsággal, és legkevésbé femininorientációval. 
Mindig követni kell a vezető utasítását

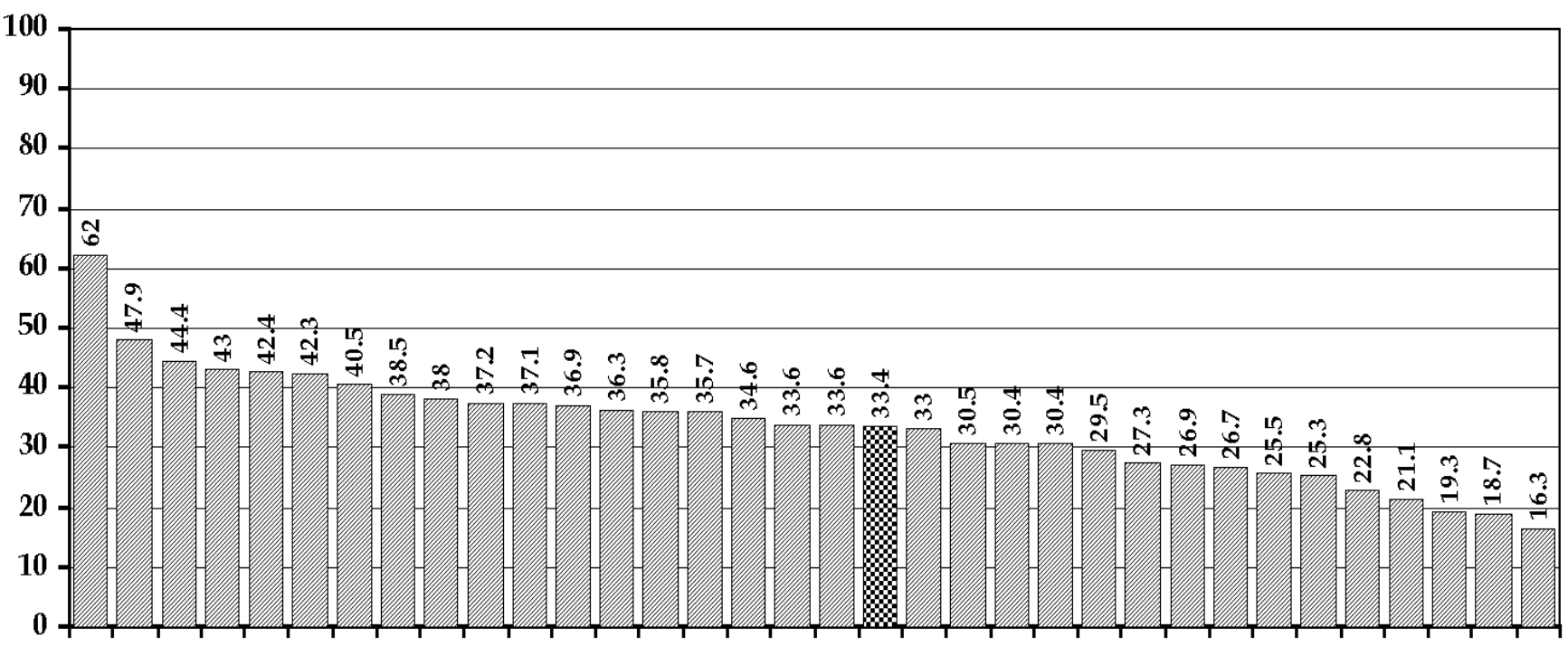

NO N- GB HU PT IS RU GR SE UA IE ES DE BG DK RO FR SK Eu LU CZ BE FI MT NL IT LV PL AT HR EE LT SI BY

Csak akkor kell követni az utasítást, ha meg vagyunk győződve helyességéról

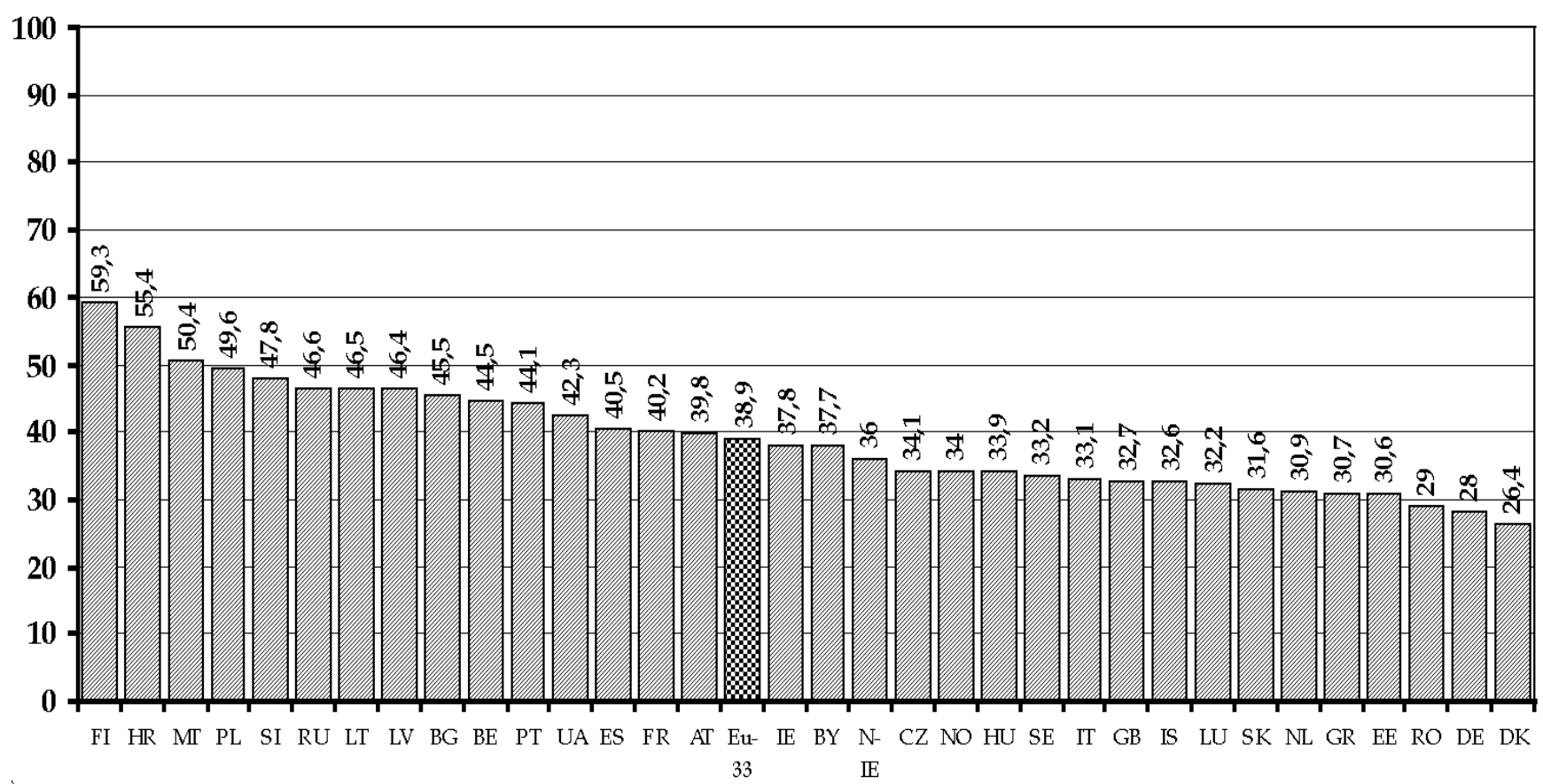

Az EVS és a GLOBE más-más kérdéseket tesz fel, és eltérô módszerekkel dolgozik, így eredményei nyilvánvalóan nehezen, illetve egyáltalán nem hasonlíthatók össze. Az EVS-ben vizsgált közép- és kelet-európai országok közül csupán HU, PL, RU és SI esik a GLOBE kelet-európai klaszterébe. Mindezek ellenére csábító gondolat egymás mellé tenni néhány tényezôt, így a GLOBE-kutatásban a kelet-európai klaszterre ki- mutatott nagy hatalmi távolságot és az EVS-ben megjelenô vezetói utasitáskövetést. A magyar és orosz válaszadók európai viszonylatban magas arányban fejezték ki egyetértésüket a felettes utasításának követésével, akkor is, ha a beosztott nem ért egyet az instrukcióval (43, illetve 40,4\%). Ez a viszonyulás egybeesni látszik a GLOBE megállapításával, hiszen a nagy hatalmi távolság kizárja a vezetô utasításának megkérdőjelezését. 
A magyar viszonyokat elemezve, más kutatási módszerrel dolgozva Danis és Parkhe is a nagy hatalmi távolságot bizonyító megfigyeléseket ír le: „A magyar menedzserek általában autokratikusabbak és jobban érzik magukat hatalmuk nyílt gyakorlása közben, mint nyugati kollégáik. ...Ha (Magyarországon) a menedzser mond valamit, a magyarok követik azt. Szerepük sokkal nagyobb hatalommal van felruházva ahhoz, hogy megmondják a beosztottaknak, mit kell tenniük." (Danis - Parkhe, 2002: 437. old.)

Nézetem szerint a hatalmi távolság és az autokratikus vezetési stílus mellett a magyarok mentalitásában is keresendő a magyarázat arra, hogy miért nem utasítják vissza a helytelenített vezetói instrukciót. Nagy valószínúséggel közrejátszik a nyílt konfrontáció kerülése. Újabb felmérések azt igazolják, hogy a magyarok nem vállalják fel a nyílt verbális konfliktust. Ezt támasztja alá Hofmeister-Tóth - Kainzbauer - Brück - Neulinger (2005: 10. old.) és hasonló következtetés vonható le a GLOBE 3,58-as asszertivitási mutatójából, amely a kelet-európai klaszterben a 7 fokozatú skálán a közepes körül mozog, és mérsékelt agresszivitásra utal (Bakacsi et al., 2002: 75. old.). A mentalitásban tükröződik a magyar népi bölcsesség: „Ne szólj szám, nem fáj fejem!” „Mondd meg az igazat, betörik a fejedet!” További feltételezett visszatartó eró, hogy még mindig alacsony a vállalatoknál az információmegosztás hajlandósága. A beosztottak ezért racionálisan járnak el, ha azt gondolják, ,,a főnök nyilván jobban tudja, mi a helyes megoldás, hiszen az ó kezében van az információ, bizonyára tud valamit, amit és nem tudok". Fink és Meierewert is arról ír, hogy információ-visszatartás jellemzi a kelet-európaiakat. „A döntéshozatal a vezető feladata, fel van hatalmazva a döntés jogával. Az információ nehezen megszerezhető és nem továbbadandó jószág" (Fink - Meierewert, 2004: 74. old.).

A GLOBE kelet-európai klaszterében szereplő másik két országban, Lengyelországban és Szlovéniában azonban sokkal kevesebben vannak, akik ,vakon” követik az utasítást (25,5 és 18,7\%), illetve, lényegesen többen, akik csak akkor tesznek eleget az instrukciónak, ha meg vannak győződve annak helyességéról $(49,6$ és 47,8\%). Ez a magatartás viszont nehezen fér össze a nagy hatalmi távolság kategóriájával.

Az EVS ráirányította a figyelmet egy másik kérdésnek, a biztos munkahelynek magasra értékelésére is. Felvetődik a kérdés, hogy kereshetô-e kapcsolat a bizonytalanságkerülési dimenzió és a biztos munkahely megbecsülése közt. A GLOBE-kutatás a kelet-európai klaszterre vonatkozóan alacsony bizonytalanságkerülési mutatót talált. Ebból az következne, hogy a klaszterbe tartozók nem rettegnek a biztos munkahely elveszítésé- tốl. Viszont a közép- és kelet-európai 14 ország a biztos munkahelyet egyöntetúen fontosnak tekinti, és a magas fizetés mögé a második helyre helyezi, szemben az európai 33 ország átlagával, amely a kellemes munkatársakat, de még az érdekes munkát is fontosabbnak tartja, mint a munkahely biztos voltát. Milyen magyarázat adható erre? A keleti 14-ben korábban a munkanélküliség ismeretlen volt, mára fenyegetettséget jelent. A munkájukat elvesztố családoknak nem csupán az ismeretlen helyzettel kell megbirkózniuk, hanem a nagyon nehéz anyagi következményekkel is. Nincsenek megtakarításaik, amelyekkel át tudnák hidalni a munkakeresés időszakát. Sem pszichikailag, sem anyagilag nincsenek felkészülve a helyzet kezelésére, és a megnyugtató társadalmi megoldás is hiányzik. A munkahely elvesztése a család teljes anyagi összeomlását és társadalmi lecsúszását jelentheti. A biztos munkahely értékét tehát nem pusztán a bizonytalan helyzet kerülése határozza meg, hanem a szinte elkerülhetetlen nagymértékú anyagi veszteség kivédése is.

\section{A kulturális standardok modell alapján folyó kutatások}

A 90-es években a kvantitatív módszerek mellett a kvalitatív és ötvözött módszerú vizsgálatok is terjednek a kultúrák összehasonlításában. Közülük a kulturális standardok modell nyer egyre inkább teret. A modell Alexander Thomas német pszichológustól származik (Thomas, 1993), aki a kulturális standardok fogalmát egy-egy kultúrára jellemzó tájékozódási rendszerként értelmezi, amely befolyásolja a társadalom tagjainak érzékelését, gondolkodását, értékítéletét és cselekedetét. Az adott normáknak, standardoknak megfelelő viselkedést a kultúrközösség tagjai normálisnak, magától értetődőnek, szokásosnak és kötelezőnek tekintik. E standardok szabják meg a közösség tagjainak viselkedését, szokásait. Vizsgálatuk kultúrapáronként eredményes: egy választott kultúra aspektusait egy másik kultúra nézőpontjából írja le. A modellre épülő kutatás ,egy bizonyos kultúra képviselőinek „,szemüvegén” keresztül vizsgálja egy másik kultúra képviselőit” (Topcu, 2005: 2. old.). A két kultúrát összehasonlítva kontrasztok kristályosodnak ki (Schroll - Machl - Novy, 2003). Az elmúlt évtized során Európán belül maradva német - magyar, német - cseh, osztrák - magyar, osztrák - kelet-európai és osztrák - cseh vizsgálatokról láttak beszámolók napvilágot.

Fink és Meierewert osztrák nézőpontból vizsgálja a kelet-európai kooperációk tanulságait, és azt állapítja meg, hogy a kelet-európaiak munkához kapcsolódó fó viselkedési standardjai a kockázatkerülés, a vezetóknek biztosított prioritások, a kollektívákban való dolgozás, a harmóniára törekvés és az ,arc megőrzése". E kulturális standardokból a szerzók egy sor, a kelet-európaiakat jellemző idômenedzselési problémát vezetnek le, így a feladatmegoldások lassúságát, a tárgyalások és a döntéshozatali folyamatok idóben elhúzódását, a (tárgyaló)partner idejének vesztegetését (Fink - Meierewert, 2004: 61. old.). 
Borgulya és munkatársai 1997 és 2000 között Magyarországon és Ausztriában múködő nemzetközi vegyes vállalatoknál, multikulturális vállalatoknál végeztek felmérést kvantitatív és kvalitatív módszert kombinálva. ${ }^{11}$ A munkavégzés során kölcsönösen azonosított viselkedési jellemzók (pontosság, minőségi munkára törekvés, kezdeményezés, rugalmasság, gyors problémamegoldás, az önmegvalósításra törekvés, a hibák felvállalása, a felelősség lerázása, megbízhatóság stb.) kérdốíves leképezése mellett kölcsönösen megélt, a munkában feltúnó, zavaró, feszültséget keltô, kritikus interakciós helyzeteket, illetve pozitív kicsengésú történeteket is lejegyeztek az interjúk készítói. A vizsgálatba magyar-brit, magyar-dán, magyar-finn, magyar-német és magyar-osztrák kölcsönös nézőpontok kerültek be. A 130 válaszadó közül 34-en dolgoztak magyar - ,germán” (német és osztrák) együttmúködésben. Német perspektívából nézve a következő, olyan kritikus tényezók derültek ki, amelyek észlelését a megkérdezettek kölcsönösen megerősítették:

A magyar vállalati struktúrában nincsenek világosan lehatárolva a hatáskörök és kompetenciák, emiatt gyakran nem világos, ki dönthet egy adott kérdésben, illetve ki a felelős. További probléma, hogy e hatáskörök gyakran változnak. (Így fordulhatott elő, hogy egy kőbánya megvásárlásában érdekelt német vállalat képviselôii három tárgyalási körben, más-más magyar vállalatképviselókkel találták szemben magukat, akik, a korábbi megállapodásokat figyelmen kívül hagyva, merốben más feltételekkel álltak elő, hangoztatva, hogy a korábbi magyar tárgyalófelek nem voltak illetékesek az értékesítési feltételek meghatározásában.)

A magyar munkavállalók vállalat iránti lojalitása alacsonyabb, mint a Nyugat-Európában megszokott. A képzett munkaerô - külföldi szemmel nézve - jelentéktelen fizetéskülönbséggel „elcsábítható” más vállalatokhoz. A fiatal diplomások között különösen erős a fóváros elszívó hatása. (Jellemzô helyzetnek ítélte a vidéki autóalkatrész-gyártó üzem magyarországi német vezetôje, hogy az anyavállalat Németországban saját költségére továbbképzi a hiányterületeken (például kontrolling, logisztika) a fiatal magyar munkatársakat, akik visszaérkezve a vidéki vállalathoz, bővített tudásuk birtokában a legrövidebb úton igyekszenek magasabb fizetésért más, fóként budapesti vállalatokhoz szegődni. A belülról fakadó lojalitás hiányában kénytelenek a német vállalatok szankcionáló intézkedéseket hozni.)

A teljesítmény kevésbé fontos, mint a jó emberi viszony megórzése. A teljesítményre vonatkozó megalapozott negatív kritika gyakorta elmarad azért, hogy a kapcsolat ne sérüljön. (Az adatszolgáltató munkatársnak nem lehet megmondani, hogy felületessége miatt használhatatlan a leadott anyaga, mert „megsértődik”. Így azután középvezetô felettese rendre maga dolgozza át az anyagot.)

Helytelen az idómenedzselés gyakorlata. A kritika lényege nem az, hogy a magyarok nem tartják be a határidôket, idópontokat, hanem az, hogy minden a határidô lejárta elôtti „finish”-ben, nagy hajtásban készül el. Ilyenkor képesek a magyarok éjjel-nappal dolgozni, hogy behozzák a lemaradást. A határidốt tartják, a minóség azonban csorbát szenved.

A személyes kapcsolatok nagy jelentóséggel birnak, és átszövik a vállalatot és a gazdaságot. A barátok, családtagok, ismerősök segítik egymást, míg a „hivatalos úton" eljáró kívülállók hátrányokat szenvednek (anekdotaszámba menő történetek gyúltek össze arról, hogy hogyan lehet gyorsan intézkedni például különböző engedélyeztetési ügyekben).

A munkahely a magánéletnek is színtere. A személyes ügyek intézése, a problémák megosztása a munkatársak között természetes dolog, és gyakoriak a munkahelyi barátságok, mély kapcsolatok.

Gyakori a törvényileg még megengedett és a törvénybe ütközés keskeny határmezsgyéjén való mozgás. (Az állandó jogszabályváltozások nagy alkalmazkodóképességet kényszerítenek ki, amibe a szabályok megkerülése is belefér.)

A teammunka fejletlen, a vállalati teammunkának nincs kidolgozott magyar gyakorlata. (Az összjáték helyett könnyen megjelenik a belsó rivalizálás, sok az „okoskodó”, a team belsố szabályait be nem tartó munkatárs.)

Nagy az információ-visszatartás (Borgulya, 2000; Borgulya, 2003; Száraz, 2004).

A kommunikációt a nyíltság hiánya és indirektség jellemzi. Ritka a direkt módon tagadó, visszautasító nem válasz, helyette inkább a feladat csendes ,elszabotálása", az ígéret meg nem tartása következik be.

A munkahelyek kommunikációja informális. Vezetók és beosztottak között a kommunikációban nem tükröződik nagy távolságtartás, a hangnem közvetlen.

Rossz a kritika kezelése. Egy konkrét megoldás, megnyilvánulás kritikája is személyes megbántódást, sértődést okoz.

\section{A kommunikációt elóitéletek nehezítik (Borgulya, 1999).}

A kulturális standardok modelljére építve Szalay Györgyi 2001 és 2002 során 45 német és 30 magyar vállalati vezetố és beosztottja interjúját feldolgozva, és további 30 beszélgetést folytatva állapított meg jellegzetességeket a munkában megnyilvánuló kulturális különbségek és a kommunikáció vonatkozásában (2002). 
Ezek közül német - magyar viszonylatban a magyarok kevésbé analitikus probléma-megközelítése, kevésbé strukturált munkavégzése, improvizálása, kevéssé kiforrott önállósága, mérsékelt felelösségvállalási készsége, patriarchális, kevéssé kooperatív vezetési stílusa, a felelósség delegálásának és a világos célok kommunikálásának hiánya, a pontosságnak a németekhez viszonyítottan kevésbé fontossággal kezelése, a magyarok udvarias, a nyílt vitakultúrát megakadályozó érintkezése, a nók kevésbé emancipáltsága emelhetô ki (Szalay, 2005: 31-32. old.), de megjelenik a személyes kapcsolatok fontossága is (Szalay, 2002: 100., 109. old.).

A fenti felmérések eredményei több ponton is megerôsítik egymást. Ilyen pont a kapcsolatorientáció. Ez a tényezố a GLOBE-felmérés humánorientációjával társítható, és valamelyest kapcsolódik a csoportkollektivitáshoz is. Bakacsi és munkatársai a kelet-európai klaszterról azt állapítják meg, hogy a humánorientáció (a csoport tagjai közötti elózékenység, önzetlenség, kedvesség) a középmezőnyben foglal helyet (Bakacsi et al., 2002: 75. old.). A kulturális standardok modell alapján végzett vizsgálatok erős kapcsolatorientációt mutatnak ki. További vizsgálódások is azt erôsítik meg, hogy Magyarországon a munkatársakhoz fúzơdő jó kapcsolat kialakítása fontos. „Magyarországon a munkahelyi kapcsolatokra a barátságos légkör a jellemzó. Meglétét nélkülözhetetlennek tartják a megfelelő munkamenet biztosításához. A munkahelyi baráti kapcsolatok nemcsak személyes beszélgetésekre terjednek ki: a kollégák gyakran töltik együtt szabadidejüket, vagy hívják meg egymást otthonaikba" (Hofmeister-Tóth et al., 2005: 8. old.). „Magyarországon nagyon fontos, hogy az ember leírja az embertársaihoz füződő viszonyát. ... A magyar menedzserek nagyobb hangsúlyt fektetnek személyes életükre" (Danis - Parkhe, 2002: 435. old.).

E megállapítások fényében meglepő, hogy az EVS megállapításaiból nem az túnik ki, hogy a kelet-európaiak számára a kellemes munkatársak fontosabbak lennének, mint a nyugat- és észak-európaiak számára. Ellenkezóleg: a 19 nyugat- és észak-európai ország átlaga: 73,1, míg a közép-kelet-európai 14 országé 66,7, de tény, hogy - mint láttuk - a kellemes munkatársak fontossága a szlovéneknél igen magas, a legmagasabb valamennyi európai érték között (90), és a magyaroknál is 85 . Ugyanakkor a szlovákoknál csak 51,1 , a litvánoknál pedig 32,1.

A kulturális standardokra épülő német-cseh viszonylatban végzett felmérés (Schroll - Machl - Novy, 2003) a csehek személyes orientációját emeli ki - a viszonyulás aspektusa fontosabb, mint a tartalom aspektusa. Ebból következóen a struktúra kevésbé jelen- tốségteljes a csehek számára, mint a németek számára. Nagyobb az improvizáció szerepe, és szimultán munkavégzés jellemzố. Az ellenôrzés általános szabályok érvényesítése helyett személyorientált. Kommunikációjukat tekintve a csehek a németekhez képest kevésbé direktek és kevésbé explicitek.

Ezek a megállapítások igen sok hasonlóságot mutatnak a német-magyar viszonylatban szerzett tapasztalatokhoz. Ugyanakkor a GLOBE a cseheket nem sorolja a kelet-európai klaszterbe, és az EVS is jelentós eltéréseket állapít meg a munkához kapcsolódó aspektusokban.

\section{Következtetések}

Az EVS, a GLOBE és a kulturális standardok kutatási módszerrel végzett felmérések Közép- és Kelet-Európa országaiban fontos ismérveket tártak fel a munkához kötődő értékekben és viselkedésekben. A kutatások olykor egymást megerôsítő, olykor egymásnak ellentmondó, de leginkább egymást kiegészítő jellemzóket állapítottak meg. A kutatásokat folytatni kell, mert bonyolult, sokszor helyzetfüggó jelenségeket szeretnénk leírni a gyakorlatban hasznosítható módon. A törekvés csak igen sokrétú kutatómunkával kivitelezhetô.

A közép- és kelet-európai országok a felmérések tükrében egyértelmúen mutatnak fel közös jellemzóket a munkához kötődő értékek megítélésében. Ilyennek tekinthetôk:

- személy-/kapcsolatorientáltság, a humán szempontok munkahelyi dominanciája - szemben a feladatorientáltság lehetóségével,

- az időnek a nyugat- és észak-európai országokhoz viszonyítva eltéró menedzselése,

- a jó fizetés fontossága,

- a biztos munkahely felértékelődése.

A vizsgált 14 közép- és kelet-európai ország azonban számos eltérô ismérvvel is rendelkezik.

- Szembeötlően elkülönül az országok két csoportja: egyrészt a sok tényezôvel motiválható szlovének, magyarok, horvátok, lengyelek és románoké, akik a munka aspektusai közül sok szempontot tartanak fontosnak. Közöttük a 15 aspektusból 11-et sokkal többen ítélnek lényegesnek, mint az európai átlag. Elkülönül másrészt a korlátozott eszközökkel motiválható szlovákok, csehek, litvánok és lettek csoportja, akik a fizetésen, a munkahely biztonságán és a munka érdekességén kívül más tényezóket nem tekintenek dominánsnak.

- Eltérések vannak az EVS szerint a vezetốk utasításának követésében is. Hat olyan közép- és kelet-eu- 
rópai ország van, amelyben többen követik ellentmondás nélkül a vezetố utasítását, mint az európai átlagban, akkor is, ha nincsenek meggyőződve annak helyességérôl.

- A vizsgált 14 országot a GLOBE-felmérés sem találja egymáshoz közeli ismérvekkel jellemezhetőnek. Közülük a kelet-európai klaszterbe csupán Lengyelországot, Magyarországot, Oroszországot és Szlovéniát sorolja.

A felelôsségteljes munka az EVS alapján néhány közép- és kelet-európai ország munkavállalói számára jóval fontosabb, mint az európai átlagnak, ami cáfolni látszik a kritikus interakciós helyzetekben leírt keleteurópai vonakodást a felelôsségvállalástól.

Tekintettel a különbözőségekre, a multikulturális vállalatok vezetóinek differenciált vezetési elveket és technikákat kell érvényesíteniük különböző közép- és kelet-európai kultúrákban szocializálódott munkatársaikkal szemben.

A magyarok igen magas arányban tartanak számos, a munkával kapcsolatos tényezốt fontosnak. A munkavégzés a szociális biztonság mellett belsố megelégedettséget, a társas és társadalmi hatásokból eredó örömöt, jóérzést és önbecsülést is jelent számukra. A motiválhatóságnak ez a széles skálája gyümölcsöztethetô az emberieróforrás-menedzsmentben, és figyelmet érdemel a vezetési rendszerek kimunkálásában.

\section{Lábjegyzet}

1 Az ITIM 5-D Pocket Guide Magyarországot alacsony hatalmi távolságú (19), közepesen individualista (55), erôsen maszkulin (79) és igen erôsen bizonytalanság kerülő (83) országként jellemzi.

2 Az EVS felmérést Magyarországon az MTA Politikatudományi Kutatóintézete gondozza. A forrásirodalomban ... neve jelzi a munkát.

${ }^{3}$ A GLOBE Magyarországon a Budapesti Közgazdaságtudományi, illetve jogutódja a Budapest Corvinus Egyetem székhellyel folyik és Bakacsi Gyula nevével forrott össze.

${ }^{4}$ Kisebb publicitást kapott a Pécsi Tudományegyetemen az 1990es évek közepén a STRATOS módszerével végzett kutatás, amely a kis- és középméretú vállalatok értékrendjét és stratégiai magatartását vizsgálta.

${ }^{5}$ Heidrich Balázs; Primecz Henriett és Soós Á.; Jarjabka Ákos; Derjanecz Ágnes kutatásai; a veszprémi Pannoon Egyetemen indított SMILE projekt, amelyet Gaál Zoltán és Szabó Lajos publikációiból ismerhetett meg a szakma

${ }^{6}$ Borgulya Istvánné német - magyar; Szalay Györgyi német - magyar; Kainzbauer - Brück; Horváth - Meierwert, továbbá Hofmeister -Kainzbauer -Brück - Neulinger osztrák - magyar, valamint Topcu Katalin osztrák - magyar összehasonlításai

7 Az EVS-ben 32 európai ország vett részt. Norvégia nem volt közöttük. Viszont bekapcsolódott a WVS-be, így az onnan nyert adatokkal kiegészítve beszélünk 33 európai országról (eu-33)

${ }^{8}$ Ausztria $=$ AT, Belgium $=$ BE, Belorusszia $=$ BY, Bulgária $=$ BG, Cseh Köztársaság = CZ, Dánia $=$ DK, Észak-Írország $=$ N-IE, Észtország= EE, Finnország = FI, Franciaország = FR, Görögor- szág $=$ GR, Hollandia $=$ NL, Horvátország $=$ HR, Izland $=$ IS, Írország = IE, Lengyelország $=$ PL, Lettország = LV, Litvánia = LT, Luxemburg = LU, Magyarország = HU, Málta = MT, NagyBritannia $=\mathrm{GB}$, Németország $=\mathrm{DE}$, Norway $=\mathrm{NO}$, Olaszország $=$ IT, Oroszország $=$ RU, Portugália $=$ PT, Románia $=$ RO, Spanyolország = ES, Svédország $=$ SE, Szlovákia = SK, Szlovénia $=$ SI, Ukrajna $=$ UA

${ }^{9}$ Belarus $=$ BY, Bulgaria $=$ BG, Croatia $=$ HR, Czech Republic $=\mathrm{CZ}$, Estonia $=\mathrm{EE}$, Hungary $=\mathrm{HU}$, Latvia $=\mathrm{LV}$, Lithuania $=$ LT, Poland $=$ PL, Romania $=$ RO, Russia $=$ RU, Slovakia $=$ SK, Slovenia $=$ SI, Ukraine $=$ UA

${ }^{10}$ Belarus $=$ BY, Bulgaria $=$ BG, Croatia $=$ HR, Czech Republic $=\mathrm{CZ}$, Estonia $=\mathrm{EE}$, Hungary $=\mathrm{HU}$, Latvia $=\mathrm{LV}$, Lithuania $=$ LT, Poland $=$ PL, Romania $=$ RO, Russia $=$ RU, Slovakia $=S K$, Slovenia $=$ SI, Ukraine $=$ UA

${ }^{11}$ People have different ideas about following instruction at work. Some say that one should follow instructions of one's superiors even when one does not fully agree with them. Others say that one should follow one's superior's instructions only when one is convinced that they are right. Which of these two opinions do you agree with?

${ }_{12}$ A vizsgálatba Magyarországon bevont vállalatok a foglalkoztatottak száma alapján, a 100 és 300 közötti létszámmal, a középméretúek kategóriájába tartoznak. Profiljukat tekintve termeló (gép- és autóalkatrész-, építőanyag-, egyedi múszer-gyártás, élelmiszer-elóállítás, fa-, gumifeldolgozás) és szolgáltató (közüzemi, mint gáz-, villamos energia-, víz- és hô-szolgáltatás, híradástechnika, nyomdaipar, kereskedelem) vállalakozások. Korábban kevés kivétellel állami tulajdonú magyar vállalatok voltak, a privatizáció során teljesen vagy részlegesen külföldi tulajdonba kerültek, ahol a tulajdonos a menedzsmentbe külföldi delegáltakat küldött. (Ilyenek voltak például a Hauni-Sophiana, a Délhús, a DDGÁZ, a dohánygyár). Kisebb részükben külföldi tulajdonos létesített vállalkozást (Pfannenschwarz)

\section{Felhasznált irodalom:}

Arts, W. - Hagenaars, J. - Halman, L. (2003): The cultural Diversity of European Unity. Brill. Leiden - Boston

Bakacsi Gy. - Takács S. (1998): Honnan - hová? A nemzeti és szervezeti kultúra változásai a kilencvenes évek közepének Magyarországán. Vezetéstudomány XXIX. 2. pp. 15-22.

Bakacsi Gy. - Takács S. - Karácsonyi A. - Imrek V. (2002): Eastern European cluster: Tradition and transition. In: Journal of World Business 37 (2002) pp. 69-80

Bakacsi Gy. (2006): Kultúra és gazda(g)ság - a gazdasági fejlődés és fejlettség és a GLOBE kultúraváltozóinak összefüggései. In: Menedzsmentkonferencia 2006. Tanulmánykötet, Pannon Egyetem, Veszprém

Borgulya Iné - Bencze V. - Kiss T. (1996): A kis- és középméretú vállalatok értékrendje, stratégiai magatartása. In: Marketing \& Menedzsment 6. szám pp. 30-38.

Borgulya Iné (1999): Sztereotípiák, előítéletek és a kultúraközi kommunikáció. In: Marketing \& Menedzsment 5. szám pp. 44-46.

Borgulya Iné (2000): Amagyar menedzserek és az interkulturális feladatok. OTKA - kutatási beszámoló. Pécs, PTE KTK 
Borgulya Á. (2003): Hungary as a site: Intercultural Aspects. In: Löhndorf, H. (ed.): The Cutting Edge. HTW, Chur pp. 43-51.

Brück, F. - Kainzbauer A. (2000): Cultural Standards Austria -Hungary. In: Journal of Cross cultural Competence \& Management. IKO Verlag, Frankfurt pp. 73-103.

Danis, W.M. - Parkhe, A. (2002): Hungarian-Western Partnerships: AGrounded TheoreticalModelof Integration Process and Outcomes. In: Journal of International Business Studies. 33. 3. Quaeter, pp. 423-455.

Derjanecz Á. (2000): Kelet-nyugati kooperációk Európában. Vezetéstudomány 11. szám pp. 19-24.

Dobrai-Sümegi K. (2005): Knowledge Oriented Organizational Culture and Managing Organizational Knowledge. Proceedings of the Conference on "Intercultural Knowledge Management. Challenges of Eastern and Western Europe" (Wirtschaftsuniversität Wien, November 2005). In print

Fink, G. - Meierewert, S. (2004): Issues of time in international, intercultural management: East and Central Europe from the perspective of Austrian managers. In: JEEMS 1/ 2004 pp. 61-84.

Gaál Z. - Pfohl, H-Ch. - Szabó L. - Elbert, R. (2004): A vállalati kultúra hatása a Magyarországon múködő magyar - német transznacionális vállalatok vezetési rendszerének sikerére. In: Vezetéstudomány XXXV. évf. 11. szám pp. 18-34.

Gaál Z. - Szabó L. (2006): IMAGINE. Investigation of Management Performance in International Enterprises. In: Menedzsmentkonferencia 2006. Tanulmánykötet. Pannon egyetem, Veszprém, pp. 51-59.

Halman, L. (2003): The European Values Study: A Third Wave. Tilburg. EVS, WORC, Tilburg University

Harris, Ph.R. - Moran, R.T. (1996): Managing Cultural Differences. (Fourth Edition) Gulf Publishing Company, Houston, London

Heidrich B. (1997): A vállalati kultúra magyar sajátosságairól. In: Vezetéstudomány. 4. szám. pp. 9-17.

Heidrich B. (1998): A szervezeti kultúra változásáról és a vezetés kérdéseirôl. In: Vezetéstudomány 1. szám pp. $1-10$.

Hofmeister-Tóth Á. - A. Kainzbauer - F. Brück - Neulinger Á. (2005): Kulturális értékek, kulturális dimenziók és kulturális standardok. In: Vezetéstudomány XXXVI. évf. 2. szám pp. 2-15.

Hofstede, G. (1980): Culture's Consequences: International Differences in Work-related Values. Sage, Beverly Hills, Calif.
House, R. (1998): A brief history of GLOBE. In: Journal of Managerial Psychology. Vol. 13.Nr.3/4. pp. 230-240.

House, R. - Javidan, M. - Hanges, P. - Dorfman, P. (2002): Understanding cultures and implicit leadership theories across the globe: an introduction to preject GLOBE. In: Journal of World Bisiness 37 (2002) pp. 3-10.

ITIM (1996) 5-D Pocket Guide. Institute For Training In Intercultural Management Den Haag

Jarjabka Á. (1999): A szervezeti kultúra tipologizálása tárgyalási és döntési stílus alapján. In: Gazdaság - Vállalkozás - Vezetés 3. szám pp. 43-48.

Kainzbauer, A. - Brück, F. (2000): Cultural Standards Austria - Hungary. In: Journal of Cross-Cultural Competence \& Management. 2/2000 IKO-Verlag, Frankfurt pp. 73-96.

Primecz H. - Soós Á. (2000): Kulturális különségek és kultúrák közötti együttmúködés vizsgálata egy Magyarországon múködő multinacionális és egy magyar vállalatnál kismintás kérdőíves lekérdezés alapján. In: Vezetéstudomány XXXI. évf. 6. szám pp. 35-48.

Schroll-Machl S. - Novy I. (2003): Tschechische und deutsche Kulturstandards in der Wirtschaftkooperation. Firmenkultur, Goethe-Institut Prag, pp. 7-24.

Szalai Gy. (2002): Arbeit und Kommunikation in deutsch - ungarischen Teams. Goethe Institut - DeutschUngarische Industrie- und Handelskammer, Budapest

Szalay Gy. (2005): Arbeit und Kommunikation in deutschungarischen Teams. In: Borgulya Á. (Ed.): The Enlarged EU: Cross-Cultural and Communications Aspects. PTE KTK, Pécs pp. 23-43.

Száraz E. (2004): Die ungarischen Manager mit den Augen ihrer österreichischen Geschäftspartner. In: Borgulya Á. (Szerk.): Kultúraközi, szakmai és szervezeti kommunikáció. PTE KTK, Pécs pp. 29-37.

Thomas A. (1988):Interkulturelles Lernenim Schüleraustausch, SSIP-Bulletin, 58, Breitenbach, Saarbrücken

Thomas, A. (1993): Kulturvergleichende Psychologie. Hofgrefe, Göttingen

Thomas A. (1996): Psychologie interkulturellen Handelns. Hofgrefe, Göttingen

торси K. (2005): A kultúrastandard módszer mint az interkulturális kooperációk elemzésének egyedi eszköze. In: Vezetéstudomány XXXVI. évf. 10. szám pp. 2-17.

Trompenaars, F. ( 1993): Riding the Waves of Culture. Nicholas Brealey Publ. London

Varga K. (1983): Szervezeti kultúránk koordinátái. Ergonómia, 3, pp. 21-38.

Cikk beérkezett: 2007. 3. hó

Lektori vélemény alapján átdolgozva: 2007. 4. hó 